The CER Working Paper Series on Entrepreneurship and Innovation

ISSN 2048-2426

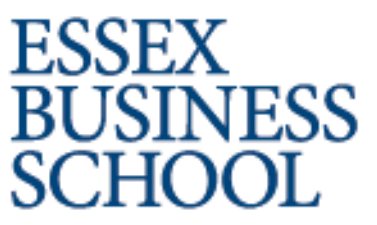

WP4

Multiple Job Holding as a Strategy for Skills Diversification and Labour Market Mobility

Georgios Panos Konstantinos Pouliakas

Alexandros Zangelidis

Number of Pages: 30

CENTRE FOR ENTREPRENEURSHIP RESEARCH

Essex Business School

University of Essex

Elmer Approach

Southend-on-Sea, Essex

SS1 1LW, UK

Tax: +44 1702328387

www.essex.ac.uk/ebs/research/cer

General correspondence to imitra@essex.ac.uk

External Advisors:

Prof David Smallbone

Prof Mathew Manimala

Prof Gunnar Prause 


\title{
Multiple Job Holding as a Strategy for Skills Diversification and Labour Market Mobility
}

\author{
August 2011 \\ Georgios Panos \\ Konstantinos Pouliakas \\ Alexandros Zangelidis
}

Corresponding Author:

Dr Georgios Panos

Essex Business School

University of Essex

Elmer Approach, Southend-on-Sea

Essex, SS1 1LW UK

Tel: +44 1702 328384, Fax + 441702328387

Email: gpanos@essex.ac.uk 


\section{Table of Content}

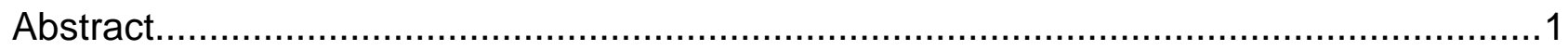

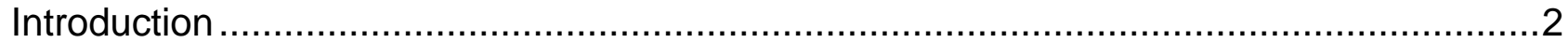

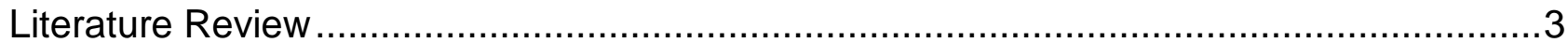

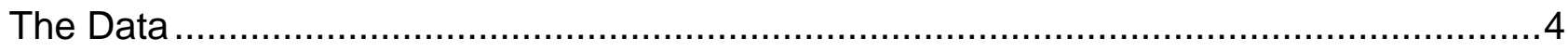

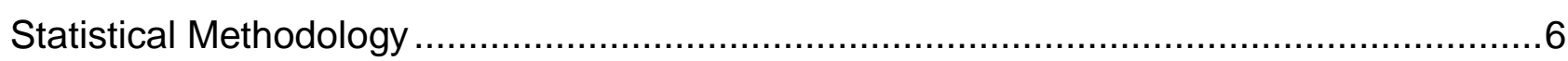

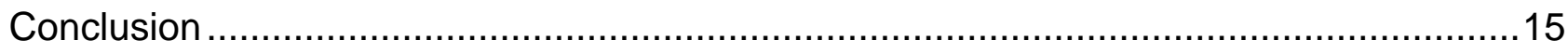

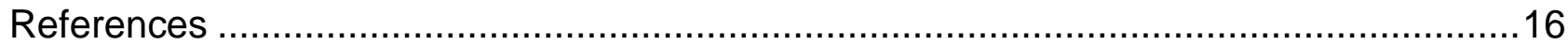

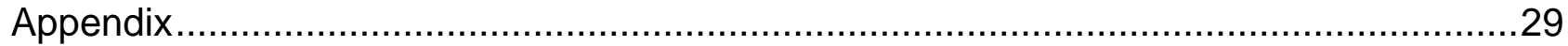




\section{Abstract}

The inter-related dynamics of dual job-holding, human capital and occupational choice between primary and secondary jobs are investigated, using a panel sample (1991-2005) of UK employees from the British Household Panel Survey (BHPS). A sequential profile of the working lives of employees is examined, investigating, first, the determinants of multiple job-holding, second, the factors affecting the occupational choice of a secondary job, third, the relationship between multiple-job holding and job mobility and, lastly, the spillover effects of multiple job-holding on occupational mobility between primary jobs. The evidence indicates that dual job-holding may facilitate job transition, as it may act as a stepping-stone towards new primary jobs, particularly self-employment.

Keywords: Moonlighting, Occupational Choice, Human Capital, Mobility.

JEL Classification Codes: J22, J24, J62 


\section{Introduction}

The shift to greater labour market flexibility in recent years (Harrison, 1998) has led to lowering employer-employee loyalty, rising unemployment risk and far shorter job durations compared to the past (OECD, 1997; Gregg and Wadsworth, 1995; 1999). In the face of these changes, the need on behalf of individuals to seek for alternative ways of ensuring employment security and a continuous and higher income stream has become paramount. In addition, with rapid technological changes requiring continuous skills updating and lifelong learning, occupational mobility has come to command a higher return in modern job markets (Gregg and Wadsworth, 1996; European Commission, 2002; EurActiv, 2010). In coping with the above volatility, a large number of workers have thus been required to foster an active strategy of multiple job-holding or moonlighting (Bell et al., 1997; Farber, 1998; Neumark, 2000).

Multiple job-holding can act as a means of tackling financial constraints, ensuring uninterrupted employment spells and as a conduit for further career progression via the accumulation of necessary occupational expertise. The phenomenon of moonlighting has become an important characteristic of the British labour market during the time period of exacerbating labour market flexibility. An examination of the employment data over recent years suggests that since 1995 more than 1.2 million people in the UK have held multiple jobs (Simic and Sethi, 2002). Böheim and Taylor (2004) report that moonlighting rates are about $8-10 \%$ for the UK labour market for the period 1991 and 1998 . Importantly, the number of people holding second jobs increased by $68 \%$ between 1984 and 2001, a disproportionate rise compared to the increase in the number of people in employment over the same period of $18 \%$.

Despite the increasing incidence of moonlighting as another facet of atypical employment, the issue remains fairly under-researched with most available studies focusing exclusively on the determinants of the decision to moonlight (Perlman, 1966; Bell et al., 1997; Conway and Kimmel, 1998; Böheim and Taylor, 2004; Dickey and Theodossiou, 2006; Renna and Oaxaca, 2006; Wu et al. 2008). However, with the notable exception of Paxson and Sicherman (1996), the literature has been surprisingly silent with respect to the important role of multiple job-holding as facilitator of skills accumulation and as determinant of the job/occupational transition process.

A close examination of the links between occupational experience, the incidence of moonlighting and job/occupational mobility, however, is crucial not only for a fuller understanding of individual income growth and career progression, but for the purposes of future labour market policy design as well. Multiple job-holding also has wider implications on employee health, productivity, work-life balance and overall well-being.

The aim of this study is to examine the links between multiple job-holding and job and occupational mobility using a panel sample of male employees observed over 15 years (1991-2005) in the UK. The empirical strategy benefits from techniques that take into consideration the dynamic character of moonlighting and simultaneously allow for individual-specific effects in outcome equations of occupational choice, defined over nonrandom sub-populations of moonlighters and job-movers. The evidence suggests that nontransferable occupation-specific experience and financial constraints are contributing factors towards the selection of similar occupations in the primary and secondary jobs by individuals who decide to moonlight. Nonetheless, those who eventually switch to a different occupation in their second job, relative to their first one, are more likely to be 
occupationally mobile in their primary job in the future, exhibiting a particular tendency to move into self-employment.

The structure of the remainder of the paper is as follows. Section 2 provides a brief review of the available literature on the economics of multiple job-holding, drawing out any implications for job and occupational mobility. Section 3 describes the data, while Section 4 outlines the empirical strategy. Section 5 discusses the main empirical results and, finally, Section 6 concludes.

\section{Literature Review}

The literature on multiple job-holding has identified four main potential motives behind moonlighting activities (Böheim and Taylor, 2004; Wu et al., 2008). The early empirical research focuses primarily on the "hours constraints" motive and suggests that the predominant explanation for multiple job-holding is financial need, i.e. multiple-job holding is used as a survival strategy for low income households. According to the standard labour-leisure model, employees may be hours constrained, i.e. willing to work more but not being offered the chance to do so in their primary occupation (Perlman, 1966). As the willingness to work more hours is related to the provision of low or insufficient wages in the first job, this is also often referred to as the financial motive. A number of empirical studies have found an association between the level of a worker's earnings and the propensity to moonlight, showing that as the level of earnings in the primary job rises the incidence of multiple job-holding declines (Hamel, 1967; Guthrie, 1969; Shisko and Rostker, 1976; Krishnan, 1990). Böheim and Taylor (2004) also find evidence that a permanent contract reduces the chances of holding a second job, suggesting an association between job security and moonlighting. However, in a recent study Robinson and Wadsworth (2007) fail to find that the introduction of the minimum wage in the UK had any significant impact on the decision to moonlight.

Apart from financial constraints, the literature has identified some additional motives for moonlighting. Heineck and Schwarze (2004) provide evidence that workers may take up a second job for other monetary benefits, acquisition of new skills or to gain experience in alternative occupations. In addition, employees may choose to find a second job in order to smooth their consumption, or as an alternative to precautionary savings, even if they are not experiencing immediate negative financial shocks (Guariglia and Kim, 2004). Furthermore, individuals might derive different sources of satisfaction from the first and the second job. In other words, job heterogeneity might provide a motivation to moonlight on its own, such as singing in a band during the evening (Böheim and Taylor, 2004). This is the so-called heterogeneity motive (Kimmel and Conway, 2001; Renna and Oaxaca, 2006).

The above arguments imply that apart from securing a continuous income stream and hedging against the risk of primary job loss, individuals may choose to take up a second job to learn about new occupations, to gain training or new credentials, to engage in activities of interest to them which provide satisfaction not received from the primary job, or to maintain flexible work schedules (e.g. a woman who requires childcare may take up two part-time jobs).

The literature also highlights some other interesting patterns governing the moonlighting phenomenon. Alden (1971) finds a higher incidence of multiple job-holding in the rural regions of the UK. He also shows that self-employment is the predominant form of employment in a secondary job. Lundberg (1995) investigates moonlighting in the context 
of a job with amenities and argues that multiple job-holding can be explained by individuals having some emotional or other attachment to a specific sector or job that would lead them to turn down offers of higher earnings in other sectors. Krishnan (1990) explores how a husband's decision to moonlight is affected by his wife's decision to work, and finds that increased participation by wives deters multiple job-holding. Kimmel and Powell (1999) find that gender and marital status also appear to affect the decision of multiple job-holding, with women, those who are never married and young individuals more likely to take up second jobs. Alden and Spooner (1982) highlight gender differences in the preferences over the type of second job, with females tending to be paid employees, as opposed to men who are mostly self-employed in their second job. In contrast, Averett (2001) finds no substantive differences in the factors that lead men and women to moonlight.

While a large part of the literature favours the "hours constraints" explanation, particularly for the developed world, little evidence has been presented on the view of multiple jobholding as a hedging strategy. Bell et al. (1997) find little evidence of behaviour of this type in the UK. They suggest that since moonlighting is more of a persistent/permanent phenomenon, this constitutes evidence in favour of the job heterogeneity explanation. In contrast, evidence from transition economies suggests that dual job-holding is more likely to be transitory and correlated with future job mobility. Guariglia \& Kim (2006) find that moonlighting in Russia is transitory and is generally associated with career shifts, often tending towards self-employment. This finding is in agreement with the view of the secondary labour market or the informal sector acting as a potential effective incubator for setting up new self-employed businesses, by fostering the development of new human capital (Levenson and Maloney, 1998; Demirgüc-Kunt et al., 2011).

In an interesting unifying framework, Paxson and Sicherman (1996) introduce a stochastic dynamic model where the decisions to take a second job and change primary job are taken simultaneously. According to the authors, the "hours constraints" explanation can lead to a dynamic process of moonlighting and job mobility. Workers who want to work more search for a portfolio of jobs that provide desirable bundles of characteristics. They may then use dual job-holding to learn about new occupations or to gain training. Moonlighting can thus facilitate the process of transition to a different occupation.

\section{The Data}

This study uses fifteen waves of the British Household Panel Survey (BHPS, 1991-2005) ${ }^{1}$ to examine the links between occupational experience, multiple job-holding, job mobility and occupational choice. The BHPS is a nationally representative household survey providing rich information on individual demographic, socioeconomic and work-related characteristics. Importantly, it identifies individuals who hold more than one job by asking "Do you earn any money from (a second job) odd jobs or from work that you might do from time to time (apart from your main job)?"

Figure 1 plots rates of dual job-holding by year vis-à-vis the official rates of unemployment, measured both in terms of benefit claimant rates per government region and local unemployment rates. The figure verifies that women are more likely to hold multiple jobs

\footnotetext{
${ }^{1}$ The BHPS data was made available through the ESRC Data Archive. The data was originally collected by the ESRC Research Centre on Micro-social Change, at the University of Essex. The original collectors of the data, the Data Archive and the affiliated institutions bear no responsibility for the analysis or interpretations presented here.
} 
than men (by almost two percentage points). The male rates are between $7 \%$ and $10 \%$, increasing in the first half of the panel and reaching a maximum in 1997. The trend declines after that year, reaching a figure close to $7 \%$ by 2005 . Echoing the evidence on the pro-cyclicality of moonlighting in the U.S (Partridge, 2002; Amuedo-Dorantes and Kimmel, 2009), the BHPS dual job-holding line also seems to parallel the unemployment line quite closely, with a rising trend until 1997 that is reversed thereafter.

\section{[Insert Figure 1 about here]}

The empirical analysis of the paper employs an unbalanced sample of males in paid employment, aged between 18 and 60 at the time of the interview. The reason for keeping male employees only is that women are more likely to undertake secondary job tasks for immediate financial reasons or due to family responsibilities (Amuedo-Dorantes and Kimmel, 2009). An additional criterion for inclusion in the analysis is the presence of males in the sample for at least three years, which is employed in order to enable the use of dynamic models. The average statistical life in the sample is 9.7 years. The sample is comprised of 5,590 individuals $(37,772$ observations). There are 3,211 spells of dual job-holding in the data, by 1,221 individuals. This is suggestive of the persistent nature of multiple job-holding in the U.K (Bell et al., 1997; Böheim and Taylor, 2004), as a large number of individuals are engaged in a second job for more than one year during the sample life.

Table 1 presents summary statistics for primary and secondary job characteristics in the sample. On average, $8.5 \%$ of the employed male sample is occupied in a second job. $52.5 \%$ of these dual job-holders are in paid employment in their second job, while the remainder are in self-employment. $61.9 \%$ hold a second job for two consecutive years (serial moonlighters). The average gross monthly salary in the primary occupation is $£ 1,329$ for an average of 39 hours of work per week. The average salary in the second job appears to be much lower, i.e. £210 for an average of 24 hours per month. Both the figures for earnings and hours of work in the second job entail very large standard deviations.

A first examination of the 1-digit Standard Occupational Classification (SOC) codes $^{2}$ in the primary and secondary jobs suggests that the proportion of people who work as "Managers \& administrators", "Plant \& machine operatives" and in "Clerical \& secretarial occupations" in their secondary occupation is significantly lower compared to the respective groups in the primary occupation. There appears to be a higher incidence of lower-skilled occupations in the second job, such as "Associate professional \& technical", "Personal \& protective service", and "Other occupations". It is thus of great interest to examine the factors that affect the decision of individuals whether to conduct the same or different types of jobs between their primary and secondary employment.

\section{[Insert Table 1 about here]}

Table 2 presents sample averages for individual and work-related characteristics. Panel $(A)$ is for the pooled sample of both dual job-holders and individuals working in a single job. Panel $(B)$ presents sample means for single job and dual job-holders, respectively, along with significance levels from a standard t-test of mean differences. Finally, Panel $(C)$ introduces another distinction of interest between individuals doing the same occupation in their primary and secondary job, and those doing a different one.

\section{[Insert Table 2 about here]}

\footnotetext{
${ }^{2}$ The robustness of the findings presented in the following sections was examined using more detailed distinctions, such as 2-digit and 3-digit level differences. The results are robust, and the choice of the 1-digit level distinction is made in order to facilitate the presentation of the output.
} 
Table 2 indicates that dual job-holders are earning significantly lower (hourly or monthly) wages in their primary job. Moreover, $13.2 \%$ of dual job-holders are found in the low-paid group, defined as those earning less than two thirds of the median earnings in the sample. The respective figure is $7.9 \%$ for those employed solely in one job. Single job-holders are also more likely to have a higher household income and are less likely to be "relatively poor" (i.e. report equivalised household income less than two thirds of the sample median). Dual job-holders are less likely to be married and to have an employed partner if married. They are younger on average and have lower labour market experience, occupationalspecific experience ${ }^{3}$ and job tenure. They work less hours on average in their primary occupation, both in terms of normal weekly hours and paid overtime. However, they are more likely to want to work more hours in that job, which is indicative of hours constraints.

A raw inspection of job transitions suggests that $4.1 \%$ of dual job-holders switch to selfemployment as a primary job in the next year, compared to $2.1 \%$ of non-moonlighters. The difference is statistically significant at the $1 \%$ level. Similarly, $14.2 \%$ of moonlighters move to a new job with a new employer, compared to $11.5 \%$ of non-moonlighters, and are less likely to remain in the same position with the same employer. These patterns suggest that there is a relationship between dual job-holding and job mobility. It is important to notice, though, that the rates of transition to unemployment and inactivity do not differ significantly between dual and single job-holders.

In terms of occupational choices, the sample averages in Panel (C) of Table 2 suggest that those dual job-holders doing the same occupation in their primary and secondary job are more likely to be wealthier and to have higher job tenure and occupational experience. The groups more likely to diversify between the two jobs are those in unskilled occupations in their primary jobs. In the first instance, the differences with respect to future job transitions are found to be statistically insignificant between individuals diversifying in their primary and secondary jobs.

\section{Statistical Methodology}

In investigating the determinants of the occupational choice at the second job, and the implications of the latter for subsequent job and occupational mobility, a number of important statistical issues arise that can be conceptualized as two distinct individual decisions. First, the analysis focuses on modeling the discrete binary choice of taking up a secondary occupation that is different from the one in the primary job. This is done in order to examine how such occupational choices are related to the various motives for moonlighting that were described in Section 2 above. Second, the interest turns to examining the potential links between the primary-secondary occupational choices of individuals at time period $t$ and their subsequent labour market mobility and occupational decisions in the next period $(t+1)$. For both set of issues the econometric methodology pays particular attention to the potential incidental selection problem that arises, given that in the first case the sample is comprised of dual job-holders only, whilst in the second the

\footnotetext{
${ }^{3}$ The creation of the occupational-specific experience variable in the BHPS stems from the detailed work of Zangelidis (2008a). Occupational experience measures the total amount of time an individual has spent in his current occupation from the time he/she first entered the job market. The variable is constructed at the 1digit level of occupation classification. Part-time and full-time paid employment spells of only salary workers are taken into consideration. The spells of occupational experience do not necessarily have to be continuous. Missing values have been imputed based on a regression model of the length of accumulated occupationalspecific experience (available upon request).
} 
sample is a non-random representation of individuals who have switched jobs. The next two sections describe the statistical methodology employed in the study.

\section{The Profile of the Dual Job-Holder and Occupational Choice}

Following the decision to take-up multiple jobs, individuals are likely to engage in a discrete choice of whether to select a secondary occupation that is different from the one in the primary job. On the one hand, undertaking a similar occupation in a second job as in the primary one may allow individuals to benefit from the specialization that may result from the accumulation of occupational-specific skills. This may constitute an optimal response, especially in the face of financial constraints that may be the motivating factor underlying the decision to moonlight. On the other hand, performing a secondary job that deviates from the original one may foster the building-up of a different stock of skills that may encourage the transition to a different occupation in the future.

This decision can be formally represented as follows:

$$
\begin{gathered}
o c c_{i t}^{(m)}=1\left\{\mathrm{x}_{i t}^{\prime} \theta+\alpha_{i}+u_{i t} \geq 0\right\}, \quad i=1, \ldots, \mathrm{N} ; t=2, \ldots, \mathrm{T} \\
m_{i t}=1\left\{m_{i t}^{*}=\mathrm{z}_{i t}^{\prime} \beta++\gamma m_{i t-1}+\eta_{i}+\varepsilon_{i t} \geq 0\right\}
\end{gathered}
$$

where in equation (1), the main equation of interest, the dependent variable, ${ }_{\text {occ }}{ }^{(m)}{ }_{i t}$, is a binary variable that takes the value of one for those who do an secondary occupation that is different from the one in their primary job (based on the 1-digit SOC), and zero otherwise. occ $^{(m)}{ }_{i t}$ is assumed to depend on a vector of regressors, $\boldsymbol{x}$, and on a composite error term, $v_{i}=\alpha_{i}+u_{i t}$, where $\alpha_{i}$ is a term capturing unobserved individualspecific effects with $E\left(\alpha_{i} \mid x_{i t}\right) \neq 0$ and $u_{i t}$ is a random error term with $E\left(u_{i t} \mid x_{i t}\right)=0$. Importantly, occ ${ }^{(m)}$ it is only observed if $m_{i t}=1$, where $m_{i t}$ is an indicator (selection) variable for individual $i$ being a dual job-holder at time period $t, \mathbf{z}$ is a vector of explanatory variables $\left(\boldsymbol{z}>\boldsymbol{x}\right.$ for identification purposes) and $c_{i t}=\eta_{i}+\epsilon_{i t}$ is a composite error term with $\varepsilon_{i t} \sim \operatorname{iidN}\left(0, \sigma_{\varepsilon}^{2}\right), E\left(\varepsilon_{i t} \mid z_{i t}\right)=0$. The time-invariant fixed effects term, $\eta_{i}$, is assumed to account for potential omitted variable bias in the model, $E\left(\eta_{i} \mid z_{i t}\right) \neq 0$, and is also responsible for serial correlation in $c_{i t}$.

Equations (1) and (2) take into account a number of important elements that are likely to characterize the economic problem that individuals face. First, the term $m_{i t-1}$ is included in Equation (2) to capture the effect of state dependence which has been identified as a typical characteristic of the decision to moonlight (Bell et al., 1997; Böheim and Taylor, 2004). Second, it has been deemed necessary to account for unobserved individual heterogeneity in the form of time-invariant fixed effects $\left(\alpha_{i}\right.$ in Equation 1 and $\eta_{i}$ in Equation 2), since there are important unobserved factors that may affect both the decision to moonlight and the subsequent occupational choice of a secondary job. For instance, it may be argued that less risk-averse individuals are more likely to engage in multiple jobholding, or to select a different occupational track as a secondary job choice. Third, a correction for potential sample selection bias is required in order to obtain consistent parameters in Equation 1, since estimation of the main outcome equation is conditional on the potentially non-random subpopulation of those individuals who decide to moonlight (Equation 2) (Heckman, 1979).

In order to address the above issues, Wooldridge (1995) and Semykina and Wooldridge (2005) have proposed a suitable Conditional Maximum Likelihood (CML) estimation 
procedure. Specifically, following Mundlak (1978) and Chamberlain (1984) it is initially assumed that the correlation between $\eta_{i}$ and $z_{i t}$ can be parameterized via a linear relationship, $\eta_{i}=\bar{z}_{i}^{\prime} \delta+\omega_{i}$, where $\omega_{i} \sim i i d N\left(0, \sigma_{\omega}^{2}\right), E\left(\omega_{i} \mid z_{i t}, \varepsilon_{i t}\right)=0$ and $\bar{z}_{i}$ are the means over the sample period of all exogenous variables. Equation (2) is therefore expressed as:

$$
m_{i t}=1\left\{\mathrm{z}_{i t}^{\prime} \beta+\gamma m_{i t-1}+\bar{z}_{i}^{\prime} \delta+\omega_{i}+\varepsilon_{i t} \geq 0\right\}, \quad i=1, \ldots, \mathrm{N} ; t=2, \ldots, \mathrm{T}
$$

As argued by Chamberlain (1984), estimation of the likelihood function requires an assumption about the relationship between the initial observations, $y_{i 1}$, and $\omega_{i}$. Assuming linearity $\omega_{i}=\omega_{0}+\omega_{1} y_{i 1}+\psi_{i}$, Wooldridge (2005) has shown that a procedure that entails the addition of the initial value, $m_{i 1}$, and the means of the time-varying exogenous regressors into the main specification (1) can lead to consistent estimation parameters: ${ }^{4}$

$$
m_{i t}=1\left\{\mathrm{z}_{i t}^{\prime} \beta+\mathrm{\gamma} m_{i t-1}+\bar{z}_{i}^{\prime} \delta+\omega_{0}+\omega_{1} m_{i 1}+\psi_{i}+\varepsilon_{i t} \geq 0\right\}, \quad i=1, \ldots, \mathrm{N} ; t=2, \ldots, \mathrm{T}
$$

Wooldridge postulates further that since the errors in the selection equation, $\varpi_{i t}=$ $\omega_{0}+\psi_{i}+\varepsilon_{i t}$, and $u_{i t}$ are independent of $\bar{z}_{i}$ and $\varpi_{i t} \sim N\left(0, \sigma_{\varrho}^{2}\right)$ and $E\left(u_{i t} \mid \bar{z}_{i}, \varpi_{i t}\right)=\rho_{t} \varpi_{i t}$, the conditional expectation of $\alpha_{i}$ can be expressed as a linear function of $\bar{z}_{i}$ and $\varpi_{i t}$ as follows:

$$
E\left(\alpha_{i} \mid \bar{z}_{i}, \varpi_{i}\right)=\bar{z}_{i} \vartheta+\left(\phi_{t}+\rho_{t}\right) E\left(\varpi_{i t} \mid \bar{z}_{i}, m_{i t}=1\right)
$$

which results in the following model of the outcome equation:

$$
o c c^{(m)}{ }_{i t}=1\left\{\mathrm{x}_{i t}^{\prime} \theta+\bar{z}_{i} \vartheta+l_{t} \lambda\left(H_{i t}\right)+u_{i t} \geq 0\right\}
$$

where $l_{t}=\left(\phi_{t}+\rho_{t}\right), H_{i t}=\left(\mathrm{z}_{i t}^{\prime} \beta+\gamma m_{i t-1}+\bar{z}_{i}^{\prime} \delta+\omega_{1} m_{i 1}\right)$ and $\lambda\left(H_{i t}\right)=\frac{\varphi\left(H_{i t}\right)}{\Phi\left(H_{i t}\right)}$ is the inverse Mill's ratio with $\varphi($.$) denoting the standard normal density and \Phi($.$) is the standard$ cumulative normal distribution function.

For the estimation of equation (6), Wooldridge recommends that separate probit regressions are estimated on the selection equation (4) per each year $t$ from which $\lambda\left(H_{i t}\right)$ is obtained (correcting the standard errors for robustness). In the second step, equation (6) may then be consistently estimated by a pooled OLS regression (with bootstrapped standard errors) ${ }^{5}$

\section{Dual Job-Holding, Job Mobility and Occupational Choice in the New Job}

The choice of primary and secondary job is likely to significantly affect the mobility of individuals via the accumulation of occupation-specific skills that it entails. As shown by Shaw (1987), in a world of perfect information the probability of employer or occupational

\footnotetext{
${ }^{4}$ Heckman (1981) had initially proposed as a solution to the initial conditions problem the specification of a linearized reduced form equation for the initial period. However, this method requires a set of exogenous instruments for identification of the full observed sequence $\left(y_{i 1}, \ldots, y_{i t}\right)$ given $x_{i}$. In contrast, Wooldridge's (2005) suggestion of modeling the density of $\left(y_{i 2}, \ldots, y_{i t}\right)$ conditional on $\left(y_{i 1}, x_{i}\right)$ minimizes both the estimation complexity and the computational cost (Stewart, 2007, p. 516).

${ }^{5}$ Other related procedures that have been suggested to tackle the above econometric problem include Kyriazidou (1997) and Dustmann and Rochina-Barrachina (2007). Applications of these methods can also be found in Jones and Labeaga (2003) and Jackle (2007).
} 
change increases with the transferability of human capital. Furthermore, imperfect knowledge of the "match" between one's abilities and the job requirements is likely to facilitate a move to an unrelated occupation. An additional job, especially one that is distinct to the primary occupation, is therefore likely to enhance the prospect of labour market mobility, by affecting the available stock of occupation-specific skills and/or by alleviating the uncertainty regarding the worker-job match.

The focus of interest therefore now turns to examining how the occupational diversification between primary and secondary jobs at time period $t$ affects the subsequent labour market decisions of individuals in the next period $(t+1)$, both in terms of their mobility to a new primary job and with respect to the occupational choice made. A similar framework to the one used in Section 4.1 is employed:

$$
\begin{gathered}
\operatorname{occ}^{(p)}{ }_{i t}=1\left\{\mathrm{x}_{i t}^{\prime} \theta+\alpha_{i}+u_{i t} \geq 0\right\}, \quad i=1, \ldots, \mathrm{N} ; t=2, \ldots, \mathrm{T} \\
p_{i t}=1\left\{p_{i t}^{*}=\mathrm{z}_{i t}^{\prime} \beta+\eta_{i}+\varepsilon_{i t} \geq 0\right\}
\end{gathered}
$$

where $o c c^{(p)}$ it is now a binary variable taking the value of one if individuals in a new primary job at time $t+1$ are doing an occupation different from their primary job in the previous period $(\mathrm{t})$. As before, an incidental truncation problem arises as this variable is only observed for those individuals who decided to change their primary employment, i.e. $p_{i t}=1$. The Wooldridge (1995) and Semykina and Wooldridge (2005) methodology is utilized again so that the estimation of equations (7) and (8) proceeds as follows ${ }^{6}$ :

$$
\begin{gathered}
o c c^{(p)}{ }_{i t}=1\left\{\mathrm{x}_{i t}^{\prime} \theta+\bar{z}_{i} \vartheta+l_{t} \lambda\left(H_{i t}\right)+u_{i t} \geq 0\right\} \\
\mathrm{p}_{i t}=1\left\{\mathrm{z}_{i t}^{\prime} \beta+\bar{z}_{i}^{\prime} \delta+\psi_{i}+\varepsilon_{i t} \geq 0\right\}
\end{gathered}
$$

\section{Empirical Results}

\section{The Profile of the Multiple Job-Holder}

The results presented in Table 3 are based on estimation of equation (4), the selection equation identifying the likelihood of individuals engaging in multiple job-holding. Apart from the terms that account for state dependence and the initial condition (Moonlighting ${ }_{(t-1)}$, Moonlighting (Year1) , the specification controls for the local unemployment rate (by administrative region), and the logarithms of equivalised household income in the year prior to the survey, labour market experience, occupation-specific experience, job tenure, weekly working hours, paid overtime hours, and number of children. Moreover, the list of explanatory variables includes dummy variables capturing whether an individual wants to work more or less hours in the primary job, marital/cohabitation status and partner's employment status, education (7 groups), and occupation in the primary job (9 groups). Finally, additional variables are included that control for private sector, permanent job, promotion prospects, and annual earnings increments in the primary job. A convenient way of interpreting the coefficients is to consider the estimated joint effect of the mean terms of the variables (Mundlak terms) and the level variables as the "permanent" effect of

\footnotetext{
${ }^{6}$ Due to the absence of any theoretical justification, no dynamic terms were used in this model.
} 
the regressors on the decision to hold a second job ${ }^{7}$. The coefficients on the level of the variables represent instead the response to a "transitory" change in these variables.

Overall the results highlight some important patterns regarding the motives of the decision to moonlight. First, there is significant evidence in favour of the financial or hoursconstraint motive, as it is clear that individuals' household income in the previous period (i.e. the period in which the decision to moonlight is likely to be made) exerts a negative effect on the probability of currently holding a second job. Furthermore, individuals who would prefer to work more hours in their present primary job are more likely to hold a second job compared to those who are content with their existing state of working hours. The opposite is also found for those who would like to work less hours. In addition, although the total number of contracted hours of work in the primary job does not affect the moonlighting decision, the number of paid overtime hours, which can act as an alternative response of individuals to financial constraints, is found to have a negative and significant effect on multiple job-holding ${ }^{8}$. Individuals with promotion prospects in their primary job and those who receive annual increments in their salary are also less likely to have a second job.

At a more aggregate level the positive effect of the current local unemployment level suggests that individuals respond to a negative demand shock, such as an increase in the unemployment rate, by obtaining a second job as an insurance shield against increased labour market uncertainty. Interestingly, the negative effect of the mean of the local unemployment rate on the probability of holding a second job suggests a supply side reaction of the labour market, as regions with high mean unemployment are likely to have a low incidence of dual job-holding due to the limited availability of jobs.

Though no temporary effects of the variables marital status, employment status of the spouse, and number of children are found, presumably due to their low variation over time, their mean effects are statistically significant. This suggests that they exert a permanent effect on the decision to hold a second job. Single people are found to be more likely to engage in moonlighting. A greater number of children, presumably due to the increased associated financial burden, is found to exert a positive impact on the decision to hold a second job. Furthermore, educational ${ }^{9}$ and occupational differences appear to explain very little of the variation in the decision to hold an additional job, although the evidence is indicative that lower-skilled occupations are more conducive to moonlighting.

The estimated model includes controls for both the multiple job-holding status of the individuals in the previous year as well as in the year they first appeared in the sample. Both variables are estimated to have a positive and statistically significant effect on the decision to hold a second job in the current period, suggesting that the incidence of multiple job-holding contains a permanent labour market element. Given the evidence of its persistent dynamic nature, it is difficult to rationalize that multiple job-holding is a temporary individual response to financial shocks. Nonetheless, the permanency of

\footnotetext{
${ }^{7}$ The joint effect is calculated as a point estimate and standard error of the linear constraint that the summation of the level and the mean effect is equal to zero, for each of the variables in the Mundlak terms separately.

${ }^{8}$ Previous research finds that the overtime premium has an ambiguous effect on the probability of moonlighting (Renna, 2006).

${ }^{9}$ An alternative model specification was also employed, where controls for education were not included in the regression to avoid potential collinearity with the occupational variables. No notable changes in effects were observed.
} 
moonlighting is consistent with previous findings of the literature that have showed that low-paid workers (who are more likely to engage in multiple job-holding) are typically trapped in a "low-pay/no pay" vicious cycle (Webb et al., 1996; Machin, 1999; Stewart, 1999; Stewart and Swaffield, 1999; Dickens, 2000; TUC, 2007).

Finally, the significant negative coefficients of a constructed measure of occupationspecific experience (Zangelidis, 2008a) and of (mean) employer-tenure implies that employees with a greater set of specific skills, who are likely to enjoy higher (wage) returns from a first job (Zangelidis, 2008a and 2008b; Kambourov and Manovskii, 2009; Williams, 2009), will be less in need of performing a secondary job. Interestingly, the level effect of tenure (transitory effect) implies that as individuals gain seniority in their current employment they are more likely to hold a second job. This finding may be potentially explained by the unwillingness of individuals to search for a second job in the initial or probationary period of employment.

\section{[Insert Table 3 about here]}

\section{Multiple Job-Holding and Occupational Choice}

Conditional on the determinants of dual job-holding shown in Table 3, the analysis now turns to the occupational choices of those who decide to have a second job i.e. the estimation of Equation (6).

The results of a Linear Probability estimator are presented in Table $4^{10}$. The list of explanatory variables is similar to that of Table 3, with the exception of the dynamic terms, and the addition of year fixed effects (i.e. dummy variables for each wave) in accordance to the methodology described in Section 4.1 for the occupational choice model. In addition, individuals who hold a second job for financial reasons are likely to compare the available employment opportunities they have and choose the one with the highest potential in terms of earnings capacity, in accordance with the prediction of standard models of occupational choice (e.g. Freeman, 1971; Boskin, 1974; Berger, 1988; Montmarquette et al., 2002). In order to capture this decision, a new variable in the dataset has thus been created that compares the wages that the individual is likely to receive from his current occupation with the predicted earnings from the best alternative occupation. The latter is defined as the occupation that individuals are most likely to do as part of their primary employment, besides the one that they are currently employed in (see the description in the Appendix for details). As expected, the estimated coefficient of this variable is negative and significant, suggesting that individuals who have higher earnings possibilities in their current occupation, relative to other viable options, are less likely to choose a different occupation in their second job.

As shown by Shaw (1987), the degree of transferability of skills across occupations is an important determinant of occupational choice, with a lower degree of transferability being associated with a greater probability of individuals selecting similar jobs. As discussed before, a measure of occupational-specific experience has thus been included in the regression as a control variable (Zangelidis, 2008a). The findings confirm a priori expectations, as individuals with lengthier occupational experience in their primary job are less likely to choose a different occupation in their second job. Interestingly, accumulated

\footnotetext{
${ }^{10}$ For robustness purposes a Probit model and a Random Effects Probit model (with no selection correction) have also been estimated. The results remain fairly similar across the different estimation procedures, so discussion only of the Linear Probability model is provided in the main text. The regression output of the alternative empirical procedures is available from the authors upon request.
} 
labour market experience is found to have the opposite (positive) effect. One plausible explanation for the latter result may be that individuals with lengthier overall working experience have better knowledge of the labour market and better information regarding employment opportunities. Furthermore, the length of total labour market experience may be regarded as a proxy of the level of accumulated general, highly transferable, skills.

Household characteristics are important determinants of individuals' occupational choice in the second job. Specifically, married or cohabitating individuals (particularly those whose spouse is not employed) are estimated to be less likely to do a different occupation in their second job, compared to that in their primary one. This finding may be interpreted as evidence that individuals with increased financial commitments are more likely to choose as their second job an occupation that that they are familiar with, as a means of increasing their earnings capacity.

Workplace characteristics of the primary job are also found to affect the occupational choice in the second job. In particular, individuals employed in the private sector are less likely to do a different occupation when engaging in multiple job-holding, while the opposite holds for those who have promotion prospects in their primary jobs. The latter may be interpreted as an indication that these individuals moonlight for non-pecuniary motives. In addition, individuals with a low level of education, compared to those with a University degree or above, are found to be less likely to do a secondary occupation different to the one in their primary job. Finally, the majority of the individuals employed in occupations other than Managers and Administrators are less likely to choose a different occupation in their second job.

Overall, the above findings imply that individuals in low-skilled jobs and/or those facing increased family commitments or financial constraints are more likely to select a similar occupation in the second job as in their primary one. This is presumably to exploit the higher earnings opportunities that their non-transferable occupational experience secures. The contrary holds for those individuals who enjoy a relative sense of financial security, who can therefore "afford" to select different occupational streams in their secondary employment that satisfy their intrinsic preferences.

\section{[Insert Table 4 about here]}

\section{Multiple Job-Holding and Job Mobility}

Focusing on the selection equation (10) first, particular interest is paid to the following five possible labour market outcomes concerning the primary employment: (1) staying in the same job; (2) becoming self-employed; (3) getting a new salary job; (4) getting a new position with the current employer; and (5) becoming unemployed or inactive. The estimation methodology is a random effects probit model ${ }^{11}$. Specifically, the four separate models estimate the probability of individuals moving to each of the four possible labour market outcomes (2),(3) and (4), relative to a comparison group of those who remain in the same job.

\footnotetext{
${ }^{11}$ This estimation methodology is considered superior to other alternatives, such as the multinomial probit model. The latter would cater for simultaneous choice between mutually exclusive options. However, that model does not allow the incorporation of individual random effects. Nonetheless, the results and interpretations from the separate four regressions shown in the next section are robust even when using a multinomial probit model (available from the authors upon request).
} 
The estimates from the random effects probit models are presented in Table 5, Panel (A). In order to assess the importance of multiple job-holding in period $t$ on the four alternative turnover patterns at period $t+1$, multiple job-holding enters the model in three alternative ways. In the first specification (I) it appears as a binary variable (Moonlighter), where a simple control for multiple job-holding in period $t$ is included. In the second specification (II), two binary variables are included that capture simultaneously the incidence of multiple job-holding and the occupational discrepancy between primary and secondary jobs (i.e. Different occupation in $2^{\text {nd }}$ job relative to the primary one in period $t$, and Similar occupation between the primary and $2^{\text {nd }}$ job in period $t$ ). Finally, in the third specification (III), two binary variables that reflect the persistency of dual job-holding activity are considered (i.e. Serial Moonlighter and Single Moonlighter $)^{12}$. The omitted category in the two latter specifications is those who do not have a second job at period $t$. The remaining explanatory variables are similar to Table 4.

It is hence found that individuals who have a second job are more likely to become selfemployed in the next period than to remain in the same job (column A1). The same is also true for getting a new job (column A2). In addition, multiple job holding is found to decrease the probability of becoming unemployed or inactive, compared to remaining in the same job (column A4). The estimates from the second specification give rise to similar conclusions, with those who have a second job in period $t$ (doing either the same or different occupation compared to their primary one) being more likely to becoming selfemployed or getting a new job in the next period. The results are also fairly similar when employing the third specification. Both serial and single moonlighters are found to be more likely to enter self-employment compared to staying in the same salary job. Single moonlighters are also estimated to have a higher probability of changing salary jobs, while the same is not true for serial moonlighters. What becomes apparent here is that the incidence of multiple job-holding itself is what affects job mobility in the next period, rather than the occupational choices individuals make in their secondary employment, or the persistency of dual job-holding activity.

The results on the remaining regressors are almost identical regardless of the chosen specification, so for that reason, and for economy of space, the estimates only from specification (I) are presented in Table $5^{13}$. Some interesting results emerge from the analysis. Local unemployment is found only to reduce the probability of moving to a new job, while it has no significant impact on all other job mobility outcomes. Furthermore, individuals with lengthier accumulated seniority and labour market experience are less likely to exhibit any kind of job mobility. Interestingly, job mobility appears to be a response to the hours-constraints individual face in their primary job. Individuals earning higher wages and those enjoying higher level of job satisfaction are found be less mobile across jobs. Also, the sector and contract of employment, as well as the promotion and salary prospects, and the travel to work time are estimated to play a significant role in job mobility outcomes.

\section{[Insert Table 5 about here]}

\section{Multiple Job-Holding and Occupational Choice in the New Job}

As the estimates in Table 5 (Panel A) highlight the importance of dual job-holding for job mobility, the issue is now further explored by examining the occupational choices

\footnotetext{
${ }^{12}$ The serial moonlighter is defined as an individual holding a $2^{\text {nd }}$ job for 2 consecutive years, as opposed to the single moonlighter who exhibits a single moonlighting spell.

${ }^{13}$ All estimates can be made available from the authors upon request.
} 
individuals make when changing jobs (either by becoming self-employed, getting a new job, or obtaining a new position with their current employer). As before, particular attention is paid on the effect of holding two jobs and the occupational choice in the second job.

The occupational choice model in equation (9) is estimated separately for those who become self-employed, get a new job or a new position at period $t+1$, with the job mobility models of columns A1-A4 serving as first stage regressions that correct for the potential incidental truncation bias ${ }^{14}$. Linear probability models are thus estimated in the second stage, incorporating the inverse Mills ratios obtained in the first stage. The dependent variable takes the value 1 if individuals work in a different occupation in (a) selfemployment (column B1); (b) new job with a new employer (column B2); and (c) new position with the same employer (column B3). The estimates are presented in Table 5 (Panel B).

Similar to above, three alternative specifications are used in order to capture the effect of multiple job-holding on occupational transitions between primary employments. What becomes evident is that the occupational choices that individuals make as multiple jobholders (specification II) can play an important role in terms of affecting their selected occupations in their new primary employment. In particular, individuals who carry out the same occupation in the primary and secondary job at period $t$ are less likely to perform a different occupation in the new primary job at period $t+1$. The opposite is true for those who do different occupations in their primary and secondary jobs at the previous period $t$. These findings suggest that there are human capital spill-over effects between primary and secondary employment. Individuals may use multiple job-holding as a conduit for obtaining new skills and expertise and as a stepping stone to a new career, particularly one that involves self-employment. The other two alternative specifications (I and III) reveal further information regarding the occupational choice in the new primary job. According to the first specification, multiple job-holders are more likely to do a different occupation that entails self-employment, compared to those who only have one job. This result appears to be driven by those who are "serial moonlighters", as can be seen by the findings of the third model.

Due to space limitations we refrain from an extensive discussion of the remaining results, though some findings merit further attention. In particular, individuals with lengthier occupation-specific experience are estimated to be less likely to change occupations in their new primary job. This is a finding that one would expect a priori, since individuals are expected to enjoy larger wage premiums by performing tasks on which they have already accumulated the necessary skills and experience. Also, those with higher seniority in their primary job at period $t$ are more likely to do a different occupation when they get a new position at period $t+1$. This may capture the effect of accumulated seniority on the probability of being promoted.

For those who get a new job at the next period, the probability of deciding to do a different occupation than before is reduced as the local unemployment rate increases. It appears that increased labour market uncertainty, as captured by the local unemployment rate,

\footnotetext{
${ }^{14}$ The exclusion restriction variables used for identification are: private sector, permanent job, promotion prospects in primary job, travel to work time and annual increments. Limited evidence of sample selection bias is found, with the inverse Mills ratio negative and significant only for those who get a new position. This suggests that the characteristics that make individuals more likely to get a new position with their current employer makes them less likely also to do a different occupation in that new position.
} 
deters people from pursuing different career paths and exploring new occupations. Also, higher earnings and job satisfaction in the previous primary job are estimated to reduce the probability of changing occupation once a job transition has taken place.

\section{Conclusion}

This study has investigated the inter-related dynamics of multiple job-holding, human capital and occupational choices between primary and secondary jobs, using a panel sample of UK employees from the British Household Panel Survey (BHPS) for the years 1991-2005. The sequential profile of the working lives of employees has been examined, investigating the motives of multiple job-holding, its impact on the probability of job mobility and the associated spillover effects on occupational transition between alternative main jobs.

The analysis reveals that multiple job-holding, in addition to being a temporary response to hours-constraints, increased labour market uncertainty, and financial shocks, contains a permanent labour market element as it appears to be persistent over time. The examination of the occupational choice in the second job also provides some interesting insights. Individuals facing increased commitments or financial constraints are found to be more likely to do the same occupation in both their primary and secondary job, exploiting the higher earnings opportunities that their accumulated occupational experience may entail. This result is further strengthened by the fact that individuals with lengthier occupational experience in their primary job are less likely to choose a different occupation in their second job. Nevertheless, individuals who enjoy a relative sense of financial security are found to be more likely to explore different occupational paths in their secondary employment to satisfy their intrinsic preferences.

Multiple job-holding is estimated to be an important determinant of job mobility decisions. Moonlighting is found to increase the probability of becoming self-employed or getting a new job, while it decreases the probability of becoming unemployed or inactive, compared to remaining in the same job. The estimates also suggest that there are human capital spill-over effects between primary and secondary employment. The occupational choices that individuals make as multiple job-holders play an important role in the occupational paths that they follow afterwards. In particular, individuals who carry out the same occupation in the primary and secondary job at period $t$ are less likely to perform a different occupation in the new primary job at period $t+1$. The opposite is true for those who do different occupations in their primary and secondary jobs at the previous period $t$. The evidence provided in this study suggests that individuals may be using multiple jobholding as a conduit for obtaining new skills and expertise and as a stepping stone to new careers, particularly ones that involve self-employment.

From a policy point of view, the findings suggest that, depending on the motives behind moonlighting, different approaches with distinct priorities and objectives may be pursued. The evidence indicates that for more vulnerable groups of people, particularly those on low incomes and with low education, moonlighting may be more of a necessity rather than a choice. Whereas, more financially stable individuals can "afford" to use multiple job-holding as an avenue to develop and enrich their skills, explore alternative career paths and pursue possible entrepreneurial activities through self-employment. The policy priorities in the first case should probably focus more on strengthening job security and on safeguarding a stable income stream to the vulnerable segments of society. Furthermore, 
issues related to work-life balance and overall well-being may warrant particular attention, since individuals who face financial hardships may be induced to compromise their physical and mental health when working in multiple jobs. For the second group of people, moonlighting may be a useful avenue through which labour market flexibility, innovation and entrepreneurship can be fostered. There is an increasing policy interest for nurturing the employability of individuals within a highly mobile and flexible labour market (Employment in Europe, 2004). Based on the results of this study, moonlighting is found to be a potential mechanism that can facilitate this process. Policy priorities could therefore focus on identifying ways through which multiple job-holding can lead to the more efficient acquisition of skills, and to promote future potential entrepreneurial initiatives.

\section{References}

Alden, J. (1971) Double jobholding: A regional analysis of Scotland. Scottish Journal of Political Economy, 18, 99-112.

Alden, J. and Spooner, R. (1982) Multiple job holders: An analysis of second-jobs in the European Community. Luxemburg: Office for Official Publications of the European Communities.

Amuédo-Dorantes, C. and Kimmel, J. (2009) Moonlighting behavior over the business cycle. Economic Inquiry, 47(4), 754-765.

Averett, S. L. (2001) Moonlighting: Multiple motives and gender gifferences. Applied Economics, 33, 1391-1410.

Böheim, R. and Taylor, M. P. (2004) And in the evening she's a singer with the band: Second jobs, plight or pleasure? IZA Discussion Paper No. 1081. Bonn, Germany: Institute for the Study of Labor.

Bell, D., Hart, R. A. and Wright, R. E. (1997) Multiple job holding as a 'hedge' against unemployment. CEPR Discussion Paper No. 1626.

Berger, M. C. (1988) Predicted future earnings and choice of college major. Industrial and Labor Relations Review, 41(3), 418-429.

Böheim, R. and Taylor, M.P. (2004) And in the evening she's a singer with the band Second jobs, plight or pleasure? IZA Discussion Paper No. 1081. Bonn, Germany: Institute for the Study of Labor.

Boskin, M. J. (1974) A conditional logit model of occupational choice. The Journal of Political Economy, 82(2), 389-398. 
The CER working Paper Series on Entrepreneurship and Innovation

Chamberlain, G. (1984) Panel data. In The Handbook of Econometrics (eds. Z. Griliches and M. Intriligator). Vol. 2, Chapter 22, North Holland.

Conway, K. S., and Kimmel, J. (1998) Male labor supply estimates and the decision to moonlight. Labour Economics. 5, 135-166.

Demirgüc-Kunt, A., Klapper, L. F. and Panos G. A. (2011) Entrepreneurship in post-conflict transition: The role of informality and access to finance. Economics of Transition, 19(1), 27-78.

Denvil, D. and Sabirianova Peter, K. (2010) Does labor supply respond to a flat tax? Evidence from the Russian tax reform. Economics of Transition, 18(2), 365-404.

Dickens, R. (2000) Caught in a trap? Wage mobility in Great Britain: 1975-1994. Economica, 67, 477-497.

Dickey, H. and Theodossiou, I. (2006) Who has two jobs and why? Evidence from rural coastal communities in west scotland. Agricultural Economics, 34(10), 291-301.

Dustmann, C. and Rochina-Barrachina, M. E. (2007) Selection correction in panel data models: An application to the estimation of females' wage equations. Econometrics Journal, 10(2), 263-293.

European Commission. (2002) Employment in Europe 2002. Recent trends and prospects. Report by the Directorate-General for Employment and Social Affairs.

European Commission. (2004) Employment in Europe 2004. Recent trends and prospects (Labour market transitions and advancement: temporary employment and low-pay in Europe). Report by the Directorate-General for Employment and Social Affairs.

European Union Information Website: EurActiv. (2010) Flexicurity: Europe's employment solution? Available at: http://www.euractiv.com/en/print/socialeurope/flexicurity-europeemployment-solution/article-169840.

Farber, H. S. (1998) Are lifetime jobs disappearing? Job duration in the United States: 1973-1993. In Labor Statistics Measurement Issues (eds. J. Haltiwanger, M. Manser, and R. Topel). Chicago, IL:: University of Chicago Press.

Freeman, R. B. (1971) The market for college-trained manpower: A study in the economics of career choice. Cambridge, MA: Harvard University Press.

Gregg, P. and Wadsworth, J. (1995) A short history of labour turnover, job tenure, and job security, 1975-93. Oxford Review of Economic Policy, 11, 73-90. 
Gregg, P. and Wadsworth, J. (1996) Mind the gap, please? The changing nature of entry jobs in Britain. LSE Discussion Paper 303, Centre of Economic Performance.

Gregg, P. and Wadsworth, J. (1999) Job tenure, 1975-98. In The State of Working Britain (eds. P. Gregg and J. Wadsworth), Manchester University Press.

Guariglia, A. and Kim, B.-Y. (2004) Earnings uncertainty, precautionary saving and moonlighting in Russia. Journal of Population Economics, 17, 289-310.

Guariglia, A. and Kim, B.-Y. (2006) The dynamics of moonlighting in Russia: What is happening in the Russian informal economy. Economics of Transition, 14(1), 1-45.

Guthrie, H. W. (1969) Teachers in the moonlight. Monthly Labour Review, 92, 28-31

Hamel, H.R. (1967). Moonlighting - An economic phenomenon. Monthly Labour Review, 90, 17-22.

Harrison, B. (1998). The dark side of flexibility. Challenge, 41,117-127.

Heckman, J. J. (1979). Sample selection bias as a specification error. Econometrica, 47(1), 153-161.

Heckman, J. J. (1981) The incidental parameters problem and the problem of initial conditions in estimating a discrete time - discrete data stochastic process. In Structural Analysis of Discrete Data with Econometric Applications (eds. C.F. Manski and D. McFadden), Cambridge, MA: MIT Press, 179-195.

Heineck, G. and Schwarze, J. (2004) Fly me to the moon: The determinants of secondary jobholding in Germany and the U.K. IZA Discussion Paper No. 1358. Bonn, Germany: Institute for the Study of Labor.

Hunt, J. C., Hill, C. R. and Kiker, B. F. (1985) The effect of taxation on labour supply: the case of moonlighting. Applied Economics, 17(5), 897-905.

Jäckle, R. (2007) Health and wages: Panel data estimates considering selection and endogeneity. Working Paper No. 43, Ifo Institute for Economic Research at the University of Munich.

Jones, A. M. and Labeaga, J. M. (2003) Individual heterogeneity and censoring in panel data estimates of tobacco expenditure. Journal of Applied Econometrics, 18(2), 157-177. 
The CER working Paper Series on Entrepreneurship and Innovation

Kambourov, G. and Manovskii, I. (2009) Occupational mobility and wage inequality. Review of Economic Studies, 76(2), 731-759.

Kimmel, J. and Powell, L. M. (1999) Moonlighting trends and related policy issues in Canada and the United States. Canadian Public Policy, 25, 207-231.

Kimmel, J. and Conway, K. S. (2001) Who moonlights and why? Evidence from the SIPP. Industrial Relations, 40, 89-120.

Krishnan, P. (1990) The economics of moonlighting: A double self-selection model. Review of Economics and Statistics, 72, 361-7.

Kyriazidou, E. (1997) Estimation of a panel data sample selection model. Econometrica, 65(6), 1335-1364.

Lemieux, T., Fortin, B. and Frechette, P. (1994) The effect of taxes on labor supply in the underground economy. American Economic Review, 84(1), 231-254.

Levenson, A. R. and Maloney, W. F. (1998) The informal sector, firm dynamics and institutional participation. World Bank Policy Research Working Paper No. 1988.

Washington, DC: The World Bank.

Lundberg, P. (1995) Job amenity and the incidence of double work. Journal of Economic Behavior and Organization, 26, $273-287$.

Machin, S. (1999) Wage inequality in the 1970s, 1980s and 1990s. In The State of Working Britain (eds. P. Gregg and J. Wadsworth), Manchester University Press.

Montmarquette, C., Cannings, K. and Mahseredjian, S. (2002) How do young people choose college majors? Economics of Education Review, 21(6), 543-556.

Mundlak, Y. (1978) On the pooling of time-series and cross section data. Econometrica, 46(1), 69-85.

Neumark, D. (2000) Changes in job stability and job security: A collective effort to untangle, reconcile and interpret the evidence. NBER Working Paper No. 7472, Cambridge, MA: National Bureau of Economic Research.

Organisation for Economic Co-operation and Development. (1997) Employment Outlook 1997.

Partridge, M. (2002) Moonlighting in a high growth economy: Evidence from U.S. statelevel data. Growth and Change, 33(4), 424-452. 
Paxson, C. H. and Sicherman, N. (1996) The dynamics of dual job holding and job mobility. Journal of Labor Economics, 14(3), 357-393.

Perlman, R. (1966) Observations on overtime and moonlighting. Southern Economic Journal, 33(2), 237-244.

Renna, F. and Oaxaca, R. L. (2006) The economics of dual job holding: A job portfolio model of labor supply. IZA Discussion Paper No. 1915. Bonn, Germany: Institute for the Study of Labor.

Renna, F. (2006) Moonlighting and overtime: A cross-country analysis. Journal of Labor Research, 27(4), 575-591.

Robinson, H. and Wadsworth, J. (2007) Impact of the minimum wage on the incidence of second job holding in Britain. Scottish Journal of Political Economy, 54(4), 553-574.

Semykina, A. and Wooldridge, J. M. (2005) Estimating panel data models in the presence of endogeneity and selection: Theory and application". Michigan State University Working Paper.

Shaw, K. L. (1987) Occupational change, employer change, and the transferability of skills. Southern Economic Journal, 53(3), 702-719.

Shishko, R. and Rostker, B. (1976) The economics of multiple job holding. The American Economic Review, 66, 298-308.

Simic, M. and Sethi, S. (2002) People with second jobs: Analysis of the trends and characteristics of people who do two jobs. Labour Market Trends, 110(5), 239-247.

Stewart, M. B. (1999) Low pay in Britain. In The State of Working Britain (eds. P. Gregg and J. Wadsworth), Manchester University Press.

Stewart, M. B. (2007) The interrelated dynamics of unemployment and low-wage employment. Journal of Applied Econometrics, 22(3), 511 - 531.

Stewart, M. B. and Swaffield, J. (1999) Low pay dynamics and transition probabilities. Economica, 66, 23-42.

Trades Union Congress. (2007) Time to tackle the training divide. Available at: http://www.tuc.org.uk/skills/tuc-13698-f0.cfm 
The CER working Paper Series on Entrepreneurship and Innovation

Webb, S., Kemp, M. and Millar, J. (1996) The changing face of low pay in Britain. Policy Studies, 17, 255-271.

Williams, N. (2009) Seniority, experience, and wages in the UK. Labour Economics, 16(3), 272-283.

Wooldridge, J. M. (1995) Selection corrections for panel data models under conditional mean independence assumptions. Journal of Econometrics, 68(1), 115-132.

Wooldridge, J. M. (2005) Simple solutions to the initial conditions problem in dynamic, nonlinear panel data models with unobserved heterogeneity. Journal of Applied Econometrics, 20(1), 39-54.

Wu, Z., Baimbridge, M. and Zhu, Y. (2008) Multiple job holding in the United Kingdom: Evidence from the British household panel survey. Nottingham Trent University Working Paper 2008/1.

Zangelidis, A. (2008a) Occupational and industry specificity of human capital in the British labour market. Scottish Journal of Political Economy, 55(4), 420-443.

Zangelidis, A. (2008b) Seniority profiles in unionised workplaces: Do unions still have the edge?. Oxford Bulletin of Economics and Statistics, 70(3), 327-345. 
Figure 1

The Incidence of Male Dual Job-Holding and Unemployment Rates

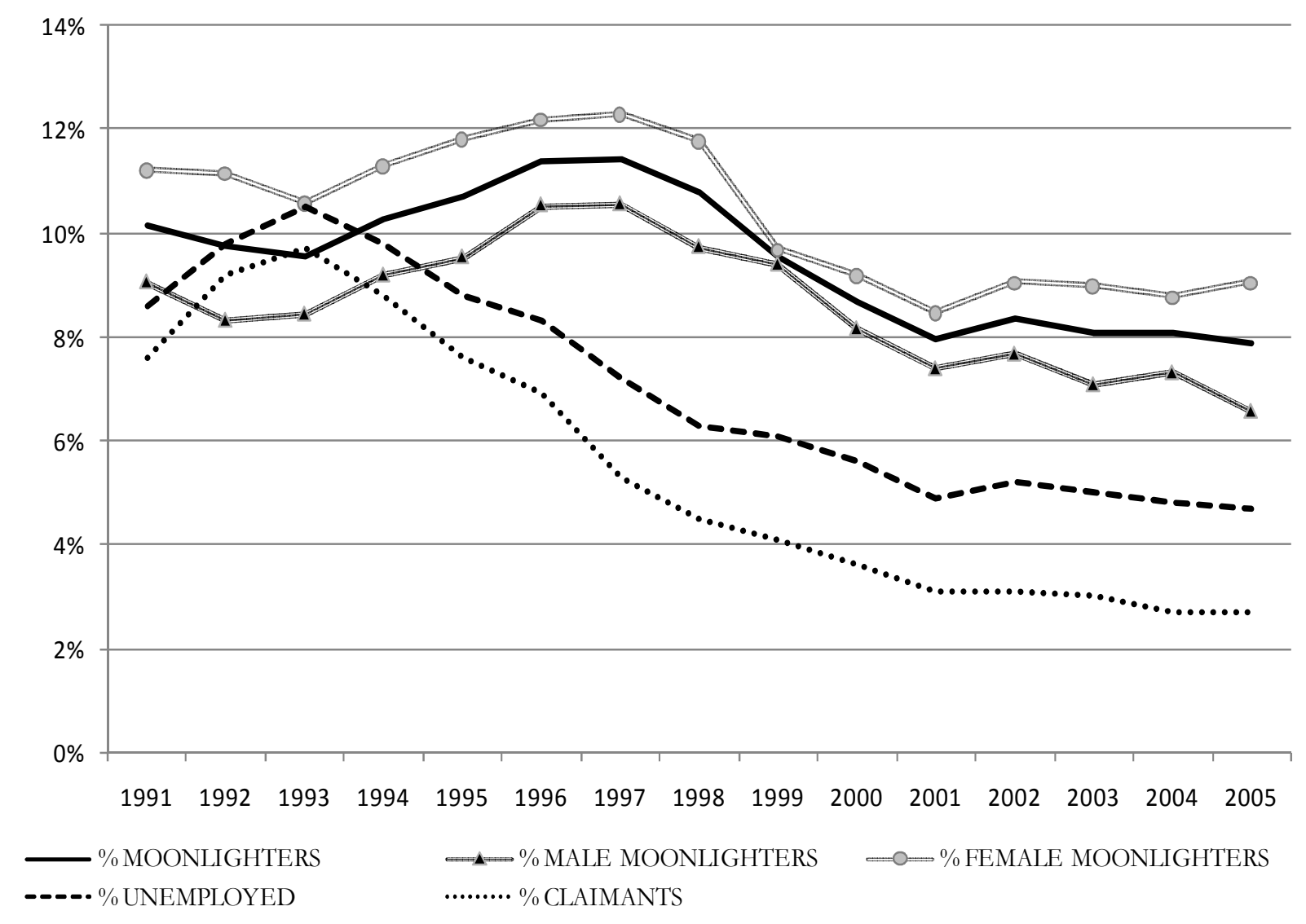

Notes:

Moonlighting data are from the BHPS. Unemployment and Local Claimants' rate data are from National Statistics Online. 
Table 1

Summary Statistics for Primary and Secondary Jobs

\begin{tabular}{lcc}
\hline $\begin{array}{l}\text { Sample of paid employees in } \\
\text { primary job }\end{array}$ & $\begin{array}{c}\text { Primary } \\
\text { Job }\end{array}$ & $\begin{array}{c}\text { Secondary } \\
\text { Job }\end{array}$ \\
\hline \multicolumn{1}{c}{ Number of Observations } & 37,772 & 3,211 \\
$\quad$ Number of Individuals & 5,590 & 1,221 \\
\hline Dual Job Holder & $8.5 \%$ & - \\
Hours of Work & & \\
\hline Weekly Hours (St.Dev.) & $39.41(7.6)$ & 5.64 \\
& & $(5.46)$ \\
Monthly Hours (St.Dev.) & 169.0 & 24.27 \\
& $(31.9)$ & $(23.5)$ \\
Real Monthly Earnings & $1,328.88$ & 209.74 \\
$\quad$ St.Dev.) & $(877.5)$ & $(400.9)$ \\
Self-Employed & - & $46.32 \%$ \\
Paid Employee & - & $52.46 \%$ \\
Different 1-digit occupation from & - & $67.3 \%$ \\
primary & & \\
Same 1-digit occupation as in primary & - & $32.7 \%$ \\
Serial Moonlighter & & $61.9 \%$ \\
$\quad$ Occupation & & \\
Managers \& administrators & $17.9 \%$ & $6.94^{\prime} \%$ \\
Professional occupations & $10.5 \%$ & $10.68 \%$ \\
Assoc. professional \& technical occ. & $10.7 \%$ & $21.92 \%$ \\
Clerical \& secretarial occupations & $9.7 \%$ & $3.83^{\prime} \%$ \\
Craft \& related occupations & $18.6 \%$ & $18.09 \%$ \\
Personal \& protective service occ. & $6.5 \%$ & $18.33^{\prime} \%$ \\
Sales occupations & $4.6 \%$ & $3.32 \%$ \\
Plant \& machine operatives & $14.7 \%$ & $5.31^{\prime} \%$ \\
Other occupations & $6.9 \%$ & $11.60^{\prime} \%$ \\
\hline \hline
\end{tabular}


Table 2

Summary Statistics and Mean Differences

\begin{tabular}{|c|c|c|c|c|c|}
\hline \multirow[t]{2}{*}{ Sample } & \multicolumn{3}{|c|}{ Employed } & \multicolumn{2}{|c|}{$\frac{\text { Dual Job Holders }}{(C)}$} \\
\hline & Pooled & Dual-Job & Single-Job & Same & Different \\
\hline Real gross usual monthly earnings & $1,340.8$ & $1,229.6$ & $1,351.3^{\star \star \star}$ & $1,367.7^{\star \star \star}$ & $1,163.1$ \\
\hline Hourly wage & 7.50 & 7.19 & $7.54^{\star * *}$ & $7.95^{\star \star \star}$ & 6.82 \\
\hline Low-paid group & $8.3 \%$ & $13.2 \%$ *** & $7.9 \%$ & $10.5 \%$ & $14.6 \%$ *** \\
\hline Real equivalized household income & $20,915.6$ & $19,945.6$ & $21,008.6^{\star * *}$ & $21,458.1^{* * *}$ & $19,228.0$ \\
\hline $\begin{array}{l}\text { Financially vulnerable group } \\
\text { Cohabiting/Married and partner employed }\end{array}$ & $18.0 \%$ & $22.7 \%$ *** & $\begin{array}{l}17.6 \% \\
58.2 \% \text { ** }\end{array}$ & $23.3 \%$ & $22.4 \%$ \\
\hline Cohabiting/Married and partner not employed & $58.0 \%$ & $55.7 \%$ & 00.210 & $\begin{array}{c}56.7 \% \\
19.4 \%\end{array}$ & $55.3 \%$ \\
\hline Single/Divorced & $15.8 \%$ & $14.9 \%$ & $15.9 \%$ & $240 \%$ & $\begin{array}{c}12.8 \% \\
32.0 \% \\
*\end{array}$ \\
\hline Age & $\begin{array}{l}26.3 \% \\
37.50\end{array}$ & $\begin{array}{l}29.4 \% \\
36.18\end{array}$ & $\begin{array}{c}25.9 \% \\
37.62^{\star \star \star}\end{array}$ & $\begin{array}{l}24.0 \% \\
36.49\end{array}$ & 36.03 \\
\hline $\begin{array}{l}\text { Potential Labour Market Experience (Age-School Leaving } \\
\text { Age) }\end{array}$ & 20.74 & 18.95 & $20.91^{\text {*** }}$ & 18.98 & 18.95 \\
\hline Occupational Experience & 11.18 & 10.69 & $11.23^{* * *}$ & $11.37^{* * *}$ & 10.37 \\
\hline $\begin{array}{l}\text { Job lenure } \\
\text { High education }\end{array}$ & 5.70 & 5.43 & $5.12^{\mathrm{nx \pi}}$ & $\begin{array}{l}5.19^{* \star} \\
26.0 \% \text { ** }\end{array}$ & 5.25 \\
\hline Middle education & $17.3 \%$ & $20.9 \%$ *** & $16.9 \%$ & 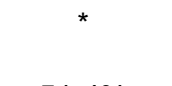 & $\begin{array}{c}18.4 \% \\
63.5 \%\end{array}$ \\
\hline Low education & $58.8 \%$ & $59.6 \%$ & $\begin{array}{c}58.7 \% \\
23.6 \% \\
*\end{array}$ & $\begin{array}{c}51.4 \% \\
21.9 \% \\
*\end{array}$ & $17.7 \%$ \\
\hline Usual Weekly Hours of Work & 39.44 & 38.25 & $39.55^{\star * *}$ & 38.57 & 38.10 \\
\hline Full-time job & $96.5 \%$ & $92.5 \%$ & $96.9 \%$ *** & $92.6 \%$ & $92.5 \%$ \\
\hline Wants to work more hours in primary occupation & $6.9 \%$ & $10.5 \%$ *** & $6.5 \%$ & $8.4 \%$ & $11.6 \%$ *** \\
\hline Wants to work the same hours in primary occupation & $55.5 \%$ & $55.9 \%$ & $55.5 \%$ & $56.9 \%$ & $55.7 \%$ \\
\hline Wants to work less hours in primary occupation & $35.6 \%$ & $31.3 \%$ & $36.0 \%$ *** & $32.4 \%$ & $31.0 \%$ \\
\hline Paid Overtime hours of work & 3.03 & 2.35 & $3.10^{\star * *}$ & 2.44 & 2.31 \\
\hline Minutes traveling to work & 26.05 & 23.72 & $26.27^{\star \star \star}$ & $24.80^{*}$ & 23.19 \\
\hline Occupation: Skilled Non-Manual Occupations & $47.0 \%$ & $47.1 \%$ & $47.0 \%$ & $56.9 \% * * *$ & $42.3 \%$ \\
\hline Skilled Manual Occupations & $10.7 \%$ & $11.8 \%$ ** & $10.6 \%$ & $17.5 \%$ *** & $9.1 \%$ \\
\hline Unskilled Non-Man & $20.8 \%$ & $22.1 \% *$ & $20.6 \%$ & $14.9 \%$ & $25.6 \%$ *** \\
\hline Unskilled Manual Occupations & $21.6 \%$ & $19.0 \%$ & $21.8 \%$ *** & $10.8 \%$ & $23.0 \%$ *** \\
\hline Managers \& administrators & $17.9 \%$ & $14.3 \%$ & $18.2 \%$ *** & $8.3 \%$ & $17.2 \%$ *** \\
\hline Professional occ & $10.5 \%$ & $15.2 \%$ *** & $10.1 \%$ & $20.6 \%$ *** & $12.6 \%$ \\
\hline Assoc. professional \& technical occ. & $10.7 \%$ & $11.8 \%$ ** & $10.6 \%$ & $17.5 \%$ *** & $9.1 \%$ \\
\hline Clerical \& secretarial occupations & $9.7 \%$ & $8.2 \%$ & $9.8 \%$ *** & $3.2 \%$ & $10.7 \%$ *** \\
\hline Craft \& related occupations & $18.6 \%$ & $17.6 \%$ & $18.7 \%$ & $28.0 \% * * *$ & $12.5 \%$ \\
\hline Personal \& protective service occ. & $6.5 \%$ & $8.9 \% * * \star$ & $6.3 \%$ & $10.2 \%$ * & $8.2 \%$ \\
\hline Sales occupations & $4.6 \%$ & $5.0 \%$ & $4.6 \%$ & $1.5 \%$ & $6.7 \% * * \star$ \\
\hline Plant \& machine operatives & $14.7 \%$ & $11.7 \%$ & $14.9 \%$ *** & $5.2 \%$ & $14.9 \%$ *** \\
\hline Other occupations & $6.9 \%$ & $7.3 \%$ & $6.9 \%$ & $5.6 \%$ & $8.2 \%$ *** \\
\hline Job Transitions in the next year: & & & & & \\
\hline Self-Employed & $2.3 \%$ & $4.1 \%{ }^{* * *}$ & $2.1 \%$ & $4.0 \%$ & $4.1 \%$ \\
\hline Paid Employee & $93.6 \%$ & $92.2 \%$ & $93.7 \%$ \%** & $92.5 \%$ & $92.1 \%$ \\
\hline Employed in a New Job with a New Emp & $11.8 \%$ & $14.2 \%$ *** & $11.5 \%$ & $14.1 \%$ & $14.3 \%$ \\
\hline $\begin{array}{l}\text { Employed in a New Position with the Same } \\
\text { Employer }\end{array}$ & $13.9 \%$ & $14.2 \%$ & $13.9 \%$ & $12.9 \%$ & $14.7 \%$ \\
\hline $\begin{array}{l}\text { Employed in the Same Position with the Same } \\
\text { Employer }\end{array}$ & $74.4 \%$ & $71.6 \%$ & $74.6 \%$ *** & $73.0 \%$ & $71.0 \%$ \\
\hline Unemployed & $2.3 \%$ & $2.1 \%$ & $2.3 \%$ & $2.3 \%$ & $2.0 \%$ \\
\hline Inactive & $1.9 \%$ & $1.7 \%$ & $1.9 \%$ & $1.3 \%$ & $1.7 \%$ \\
\hline
\end{tabular}

Notes: ${ }^{*} p<0.10,{ }^{* *} p<0.05,{ }^{* *} p<0.01$ from a t-test between mean differences. 
Table 3: The Profile of the Dual Job-Holder

Wooldridge Estimator: Dynamic Random Effects Probit with Mundlak terms

\begin{tabular}{|c|c|c|c|c|}
\hline Dependent Variable: Dual-Job Holder & Coef. & [S.E.] & M.Eff. & [S.E.] \\
\hline I. Model Specification & & & & \\
\hline Moonlighting $(\mathrm{t}-1)$ & $1.170^{* \star *}$ & [0.046] & $0.111^{* * *}$ & [0.013] \\
\hline Moonlighting $_{(Y e a r 1)}$ & $1.164^{* * *}$ & [0.075] & $0.107^{* * *}$ & {$[0.011]$} \\
\hline Log(Equivalized household income $)_{t-1}$ & $-0.114^{\star * *}$ & {$[0.044]$} & $-0.004^{* *}$ & {$[0.001]$} \\
\hline Local unemployment rate & $0.024^{*}$ & {$[0.012]$} & $0.001^{*}$ & {$[0.000]$} \\
\hline Log(Experience) & -0.151 & {$[0.094]$} & -0.005 & [0.003] \\
\hline Log(Occupational experience) & 0.011 & {$[0.034]$} & 0.001 & [0.001] \\
\hline Log(Tenure) & $0.068^{* *}$ & {$[0.026]$} & $0.002^{* *}$ & [0.001] \\
\hline Wants to work more hours in primary job & $0.203^{* * *}$ & {$[0.072]$} & $0.008^{* *}$ & [0.003] \\
\hline $\begin{array}{l}\text { Wants to work the same hours in primary } \\
\text { occupation }\end{array}$ & \multicolumn{2}{|c|}{$[R E F]}$. & \multicolumn{2}{|c|}{ [REF.] } \\
\hline Wants to work less hours in primary job & $-0.079^{*}$ & [0.044] & $-0.002^{*}$ & [0.001] \\
\hline Log(Weekly hours in primary job) & -0.073 & {$[0.105]$} & -0.002 & [0.003] \\
\hline Log(Paid overtime hours) & $-0.037^{* * *}$ & {$[0.012]$} & $-0.001^{* * *}$ & {$[0.000]$} \\
\hline Cohabiting/Married and spouse employed & -0.084 & {$[0.074]$} & -0.003 & [0.002] \\
\hline Cohabiting/Married and spouse not employed & -0.039 & {$[0.093]$} & -0.001 & [0.003] \\
\hline Single/Divorced & \multicolumn{2}{|c|}{$[R E F]}$. & \multicolumn{2}{|c|}{ [REF.] } \\
\hline Log(No. of children) & 0.008 & [0.022] & 0.001 & [0.001] \\
\hline Private sector & $-0.154^{*}$ & {$[0.090]$} & -0.005 & {$[0.004]$} \\
\hline Permanent job & -0.050 & {$[0.100]$} & -0.002 & {$[0.004]$} \\
\hline Promotion prospects in primary job & $-0.105^{\star *}$ & {$[0.045]$} & $-0.003^{* *}$ & [0.002] \\
\hline Annual increments & $-0.088^{\star *}$ & {$[0.044]$} & $-0.003^{\star \star}$ & [0.001] \\
\hline High education & & & & \\
\hline Middle education & 0.190 & [0.204] & 0.006 & {$[0.006]$} \\
\hline Low education & -0.142 & [0.332] & -0.004 & [0.009] \\
\hline Managers and administrators & \multicolumn{2}{|c|}{ [REF.] } & \multicolumn{2}{|c|}{$[R E F]}$. \\
\hline Professional occupations & 0.170 & {$[0.105]$} & 0.006 & [0.005] \\
\hline Associate professional \& technical occupations & 0.119 & {$[0.090]$} & 0.004 & {$[0.004]$} \\
\hline Clerical \& secretarial occupations & 0.158 & [0.102] & 0.006 & [0.004] \\
\hline Craft \& related occupations & 0.157 & [0.105] & 0.006 & {$[0.004]$} \\
\hline Personal \& protective service occupations & $0.365^{\star * *}$ & [0.136] & $0.017^{*}$ & {$[0.009]$} \\
\hline Sales occupations & $0.256^{* *}$ & [0.123] & 0.011 & [0.007] \\
\hline Plant \& machine operatives & 0.147 & {$[0.107]$} & 0.005 & {$[0.004]$} \\
\hline Other occupations & $0.208^{*}$ & [0.119] & 0.008 & [0.006] \\
\hline \multicolumn{5}{|l|}{ Means: } \\
\hline Local unemployment rate & $-0.045^{\star \star}$ & [0.019] & $-0.001^{* *}$ & [0.001] \\
\hline Log(Experience) & 0.166 & {$[0.102]$} & 0.005 & [0.003] \\
\hline Log(Occupational experience) & $-0.135^{\star \star}$ & {$[0.062]$} & $-0.004^{\star *}$ & [0.002] \\
\hline Log(Tenure) & $-0.157^{* * *}$ & {$[0.048]$} & $-0.005^{\star \star *}$ & [0.002] \\
\hline Wants to work more hours in primary job & 0.160 & {$[0.173]$} & 0.005 & [0.006] \\
\hline $\begin{array}{l}\text { Wants to work the same hours in primary } \\
\text { occupation }\end{array}$ & \multicolumn{2}{|c|}{ [REF.] } & \multicolumn{2}{|c|}{ [REF.] } \\
\hline Wants to work less hours in primary job & 0.026 & [0.096] & 0.001 & [0.003] \\
\hline Log(Weekly hours in primary job) & -0.007 & {$[0.185]$} & -0.001 & {$[0.006]$} \\
\hline Log(Paid overtime hours) & $0.046^{* *}$ & {$[0.022]$} & $0.001^{* *}$ & [0.001] \\
\hline Cohabiting/Married and spouse employed & -0.113 & {$[0.108]$} & -0.004 & [0.003] \\
\hline Cohabiting/Married and spouse not employed & \multirow{2}{*}{\multicolumn{2}{|c|}{ [REF.] }} & $-0.013^{* \star *}$ & [0.005] \\
\hline Single/Divorced & & & \multicolumn{2}{|c|}{$[R E F]}$. \\
\hline Log(No. of children) & $0.073^{\star \star *}$ & [0.032] & $0.002^{* \star}$ & {$[0.001]$} \\
\hline Private sector & $-0.217^{*}$ & {$[0.119]$} & $-0.007^{\star}$ & [0.004] \\
\hline Permanent job & $-0.547^{\star * *}$ & {$[0.197]$} & $-0.018^{\star * *}$ & {$[0.006]$} \\
\hline Promotion prospects in primary job & $-0.201^{* *}$ & {$[0.087]$} & $-0.006^{* *}$ & [0.003] \\
\hline Annual increments & -0.029 & {$[0.090]$} & -0.001 & [0.003] \\
\hline Constant & 0.695 & [0.694] & & \\
\hline$\rho$ & $0.435^{\star * *}$ & [0.022] & & \\
\hline II. Calculated Permanent Effects: & & & & \\
\hline Local unemployment rate & -0.021 & {$[0.014]$} & -0.001 & {$[0.000]$} \\
\hline Log(Experience) & 0.016 & {$[0.045]$} & 0.001 & {$[0.001]$} \\
\hline Log(Occupational experience) & $-0.123^{\star \star}$ & {$[0.052]$} & $-0.004^{\star *}$ & {$[0.002]$} \\
\hline Log(Tenure) & $-0.090^{* *}$ & {$[0.040]$} & $-0.003^{* *}$ & [0.001] \\
\hline Wants to work more hours in primary job & $0.363^{* *}$ & {$[0.156]$} & $0.012^{\star *}$ & [0.005] \\
\hline
\end{tabular}

Table 3 continued in next page 
The CER working Paper Series on Entrepreneurship and Innovation

Table 3 continued from last page

\begin{tabular}{|c|c|c|c|c|}
\hline Wants to work the same hours in primary & \multicolumn{2}{|c|}{ [REF.] } & \multicolumn{2}{|c|}{ [REF.] } \\
\hline Wants to work less hours in primary job & -0.054 & [0.085] & -0.002 & [0.003] \\
\hline Log(Weekly hours in primary job) & -0.081 & [0.153] & -0.003 & {$[0.005]$} \\
\hline Log(Paid overtime hours) & 0.009 & [0.019] & 0.001 & [0.001] \\
\hline Cohabiting/Married and spouse employed & $-0.197^{* *}$ & [0.078] & $-0.006^{\star *}$ & [0.003] \\
\hline Cohabiting/Married and spouse not employed & $-0.430^{* * *}$ & [0.114] & $-0.014^{\star \star *}$ & [0.004] \\
\hline Single/Divorced & \multicolumn{2}{|c|}{ [REF.] } & \multicolumn{2}{|c|}{$[R E F]}$. \\
\hline Log(No. of children) & $0.082^{\star * \star}$ & [0.023] & $0.003^{* * *}$ & [0.001] \\
\hline Private sector & $-0.372^{\star \star *}$ & [0.076] & $-0.012^{\star \star *}$ & [0.003] \\
\hline Permanent job & $-0.597^{\star \star *}$ & [0.174] & $-0.019^{\star \star *}$ & {$[0.006]$} \\
\hline Promotion prospects in primary job & $-0.306^{\star * *}$ & [0.075] & $-0.010^{\star * *}$ & [0.002] \\
\hline Annual increments & -0.116 & [0.079] & -0.004 & [0.003] \\
\hline Average Predicted Probability & \multicolumn{4}{|c|}{0.0425} \\
\hline No. of Observations & \multirow{5}{*}{\multicolumn{4}{|c|}{$\begin{array}{c}28,851 \\
5,220 \\
-5,111.3 \\
1,993.0^{\star * *} \\
513.25^{\star * *}\end{array}$}} \\
\hline No. of Individuals & & & & \\
\hline Log Likelihood & & & & \\
\hline Wald $x^{2}$ & & & & \\
\hline $\operatorname{LR} x^{2}(\rho=0)$ & & & & \\
\hline
\end{tabular}

Notes:

${ }^{*} p<0.10,{ }^{* *} p<0.05,{ }^{* * *} p<0.01$. The specification also includes a constant term and the means of all independent variables; The coefficients and standard errors of the permanent effects are derived from tests of the linear constraint that the summation of the level and the mean effect of each variable are equal to zero, e.g. $\beta$ (Local Unemployment Rate $)+\delta_{\text {(Local Unemployment Rate }]}=0$. 
Table 4

Dual Job Holding and Occupational Choice

\begin{tabular}{|c|c|c|}
\hline \multirow{2}{*}{$\begin{array}{l}\text { Dep. Var.: Different 1-digit SOC between 1st and 2nd } \\
\text { job }\end{array}$} & \multicolumn{2}{|c|}{ Linear Probability Model } \\
\hline & Coef. & [B.S.E.] \\
\hline Difference in hourly wage (primary occ. vs. next best) & $-0.092^{\star \star \star}$ & [0.030] \\
\hline Local unemployment rate & 0.005 & [0.008] \\
\hline Log (Equivalised annual household income $)_{\mathrm{t}-1}$ & -0.041 & [0.025] \\
\hline Log(Experience) & $0.050^{* * *}$ & [0.015] \\
\hline Log(Occupational experience) & $-0.047^{\star \star \star}$ & {$[0.014]$} \\
\hline Log(Tenure) & 0.013 & [0.011] \\
\hline Wants to work more hours in primary job & \multirow{2}{*}{\multicolumn{2}{|c|}{$\begin{array}{l}\text { [REF.] } \\
{[0.00<]}\end{array}$}} \\
\hline Wants to work the same hours in primary occupation & & \\
\hline Wants to work less hours in primary job & $-0.017^{L}$ & {$[0.020]$} \\
\hline Log(Weekly hours in primary job) & -0.052 & [0.041] \\
\hline Log(Paid overtime hours) & $-0.009^{*}$ & [0.005] \\
\hline Cohabiting/Married and spouse employed & $-0.082^{* * *}$ & [0.025] \\
\hline Cohabiting/Married and spouse not employed & $-0.214^{* * *}$ & [0.037] \\
\hline Single/Divorced & \multicolumn{2}{|c|}{ [REF.] } \\
\hline Log(No. of children) & -0.006 & {$[0.008]$} \\
\hline Private Sector & $-0.054^{\star *}$ & {$[0.027]$} \\
\hline Permanent job & 0.034 & {$[0.048]$} \\
\hline Promotion prospects in primary job & $0.060^{* \star *}$ & [0.021] \\
\hline Annual increments & -0.009 & [0.021] \\
\hline High education & \multicolumn{2}{|c|}{ [REF.] } \\
\hline Middle education & 0.033 & {$[0.030]$} \\
\hline Low education & $-0.105^{\star * *}$ & [0.039] \\
\hline Managers and administrators & \multicolumn{2}{|c|}{ [REF.] } \\
\hline Professional occupations & $-0.296^{\star * *}$ & {$[0.039]$} \\
\hline Associate professional \& technical occupations & $-0.323^{\star * *}$ & {$[0.037]$} \\
\hline Clerical \& secretarial occupations & -0.029 & {$[0.037]$} \\
\hline Craft \& related occupations & $-0.331^{* \star *}$ & [0.034] \\
\hline Personal \& protective service occupations & $-0.276^{\star \star \star}$ & [0.041] \\
\hline Sales occupations & 0.027 & [0.039] \\
\hline Plant \& machine operatives & $0.055^{\star}$ & [0.032] \\
\hline Other occupations & -0.057 & [0.043] \\
\hline Mills Ratio & 0.055 & [0.051] \\
\hline Constant & $1.211^{* * *}$ & [0.283] \\
\hline No. of Observations & \multicolumn{2}{|c|}{2,364} \\
\hline No. of Individuals & \\
\hline No. of Observations ( $1^{\text {st }}$ stage equation) & \multicolumn{2}{|c|}{36,980} \\
\hline Log Likelihood & \multicolumn{2}{|c|}{$-1,365.7$} \\
\hline Wald $x^{2}$ & \multicolumn{2}{|c|}{$634.7^{* * *}$} \\
\hline
\end{tabular}

Notes:

${ }^{*} p<0.10,{ }^{* *} p<0.05,{ }^{* * *} p<0.01$

The specification includes year fixed effects and a constant term. Bootstrapped standard errors in Columns (1) and (2), based on 1,000 replications. The estimates presented are from $2^{\text {nd }}$ stage regressions. The $1^{\text {st }}$ stage is a selection equation as proposed by Wooldridge (1995) and Semykina and Wooldridge (2005). The reference groups remain the same as in Table 3. 
Table 5

Job Mobility, Occupational Choice, and Dual Job Holding

\begin{tabular}{|c|c|c|c|c|c|c|c|}
\hline \multirow[t]{2}{*}{$\begin{array}{c}\text { Sample } \\
\text { Dependent Variable: }\end{array}$} & (A) & \multicolumn{3}{|c|}{ Random Effects Probit } & \multicolumn{3}{|c|}{$\begin{array}{l}\text { (B) Linear Probability Model } \\
\text { with selectivity correction } \\
\text { Job Switchers } \\
\text { Different occupation in: }\end{array}$} \\
\hline & $\begin{array}{l}\text { (A1) } \\
\text { Self-Emp. }\end{array}$ & $\begin{array}{c}(A 2) \\
\text { New Job }\end{array}$ & $\begin{array}{c}\text { (A3) } \\
\text { New } \\
\text { Position } \\
\end{array}$ & $\begin{array}{c}(\text { A4) } \\
\text { Not } \\
\text { Employed }\end{array}$ & $\begin{array}{l}\text { (B1) } \\
\text { Self- } \\
\text { Emp. }\end{array}$ & $\begin{array}{c}(B 2) \\
\text { New Job }\end{array}$ & $\begin{array}{c}\text { (B3) } \\
\text { New } \\
\text { Position } \\
\end{array}$ \\
\hline \multicolumn{8}{|c|}{ Multiple Job-Holding (three alternative specifications) } \\
\hline (I) Moonlighter & $\begin{array}{l}0.014^{* \star *} \\
{[0.003]}\end{array}$ & $\begin{array}{l}0.017^{* *} \\
{[0.007]}\end{array}$ & $\begin{array}{l}0.009 \\
{[0.008]}\end{array}$ & $\begin{array}{l}-0.007^{\star \star} \\
{[0.003]}\end{array}$ & $\begin{array}{l}0.091 \\
{[0.057]}\end{array}$ & $\begin{array}{l}-0.009 \\
{[0.027]}\end{array}$ & $\begin{array}{l}-0.014 \\
{[0.027]} \\
\end{array}$ \\
\hline $\begin{array}{l}\text { (II) Different occupation in } 2^{\text {nd }} \text { Job } \\
\text { Similar occupation between } 2^{\text {nd }}\end{array}$ & $\begin{array}{l}0.013^{\star *} \\
{[0.005]}\end{array}$ & $\begin{array}{l}0.029^{\star *} \\
{[0.013]}\end{array}$ & $\begin{array}{l}0.015 \\
{[0.015]}\end{array}$ & $\begin{array}{l}-0.007 \\
{[0.005]}\end{array}$ & $\begin{array}{l}-0.219^{\star * *} \\
{[0.077]}\end{array}$ & $\begin{array}{l}-0.131^{\star * *} \\
{[0.044]}\end{array}$ & $\begin{array}{l}-0.068 \\
{[0.044]}\end{array}$ \\
\hline Job & $\begin{array}{l}0.015^{\star \star *} \\
{[0.004]}\end{array}$ & $\begin{array}{l}0.011 \\
{[0.008]}\end{array}$ & $\begin{array}{l}0.006 \\
{[0.010]}\end{array}$ & $\begin{array}{l}-0.007^{*} \\
{[0.004]}\end{array}$ & $\begin{array}{l}0.248^{* * *} \\
{[0.064]}\end{array}$ & $\begin{array}{c}0.05 \\
{[0.034]}\end{array}$ & $\begin{array}{l}0.009 \\
{[0.032]}\end{array}$ \\
\hline (III) Serial moonlighter & $\begin{array}{l}0.015^{\star * *} \\
{[0.005]}\end{array}$ & $\begin{array}{l}-0.001 \\
{[0.010]}\end{array}$ & $\begin{array}{l}0.009 \\
{[0.012]}\end{array}$ & $\begin{array}{l}-0.010^{* *} \\
{[0.004]}\end{array}$ & $\begin{array}{l}0.204^{\star * \star} \\
{[0.077]}\end{array}$ & $\begin{array}{l}0.004 \\
{[0.044]}\end{array}$ & $\begin{array}{l}0.018 \\
{[0.037]}\end{array}$ \\
\hline Temporary moonlighter & $\begin{array}{l}0.015^{\star * *} \\
{[0.004]}\end{array}$ & $\begin{array}{l}0.029^{* * *} \\
{[0.010]}\end{array}$ & $\begin{array}{l}0.007 \\
{[0.011]}\end{array}$ & $\begin{array}{l}-0.004 \\
{[0.004]}\end{array}$ & $\begin{array}{l}0.051 \\
{[0.072]}\end{array}$ & $\begin{array}{c}-0.02 \\
{[0.034]}\end{array}$ & $\begin{array}{l}-0.043 \\
{[0.038]}\end{array}$ \\
\hline \multicolumn{8}{|c|}{ Remaining regressors based on (I) specification } \\
\hline Local unemployment rate & $\begin{array}{l}-0.001 \\
{[0.000]}\end{array}$ & $\begin{array}{l}-0.007^{* \star *} \\
{[0.002]}\end{array}$ & $\begin{array}{l}-0.002 \\
{[0.002]}\end{array}$ & $\begin{array}{l}-0.001 \\
{[0.001]}\end{array}$ & $\begin{array}{l}0.019 \\
{[0.019]}\end{array}$ & $\begin{array}{l}-0.019^{\star *} \\
{[0.008]}\end{array}$ & $\begin{array}{l}0.001 \\
{[0.007]}\end{array}$ \\
\hline Log(Real gross monthly earnings) & $\begin{array}{l}-0.001 \\
{[0.001]}\end{array}$ & $\begin{array}{l}-0.035^{\star \star *} \\
{[0.005]}\end{array}$ & $\begin{array}{l}-0.001 \\
{[0.006]}\end{array}$ & $\begin{array}{l}-0.018^{\star * *} \\
{[0.003]}\end{array}$ & $\begin{array}{l}-0.004 \\
{[0.047]}\end{array}$ & $\begin{array}{l}-0.121^{* * *} \\
{[0.023]}\end{array}$ & $\begin{array}{l}-0.015 \\
{[0.019]}\end{array}$ \\
\hline Job satisfaction & $\begin{array}{l}-0.002^{* * *} \\
{[0.000]}\end{array}$ & $\begin{array}{l}-0.027^{\star * *} \\
{[0.001]}\end{array}$ & $\begin{array}{l}-0.014^{\star * *} \\
{[0.002]}\end{array}$ & $\begin{array}{l}-0.008^{\star * *} \\
{[0.001]}\end{array}$ & $\begin{array}{l}-0.047^{\star * *} \\
{[0.015]}\end{array}$ & $\begin{array}{l}-0.021^{* * *} \\
{[0.006]}\end{array}$ & $\begin{array}{l}-0.016^{* * *} \\
{[0.006]}\end{array}$ \\
\hline Log(Experience) & $\begin{array}{l}-0.001 \\
{[0.001]}\end{array}$ & $\begin{array}{l}-0.034^{\star \star \star} \\
{[0.003]}\end{array}$ & $\begin{array}{l}-0.039^{* \star *} \\
{[0.004]}\end{array}$ & $\begin{array}{l}-0.002 \\
{[0.002]}\end{array}$ & $\begin{array}{l}0.045 \\
{[0.032]}\end{array}$ & $\begin{array}{l}-0.02 \\
{[0.013]}\end{array}$ & $\begin{array}{l}-0.002 \\
{[0.013]}\end{array}$ \\
\hline Log(Occupational experience) & $\begin{array}{l}0.001 \\
{[0.001]}\end{array}$ & $\begin{array}{l}0.002 \\
{[0.003]}\end{array}$ & $\begin{array}{l}0.001 \\
{[0.003]}\end{array}$ & $\begin{array}{l}0.005^{\star * *} \\
{[0.002]}\end{array}$ & $\begin{array}{l}-0.083^{\star * \star} \\
{[0.027]}\end{array}$ & $\begin{array}{l}-0.076^{\star \star \star} \\
{[0.013]}\end{array}$ & $\begin{array}{l}-0.072^{\star * *} \\
{[0.012]}\end{array}$ \\
\hline $\log ($ Tenure) & $\begin{array}{l}-0.004^{\star * *} \\
{[0.001]}\end{array}$ & $\begin{array}{l}-0.061^{\star \star *} \\
{[0.003]}\end{array}$ & $\begin{array}{l}-0.043^{\star \star \star} \\
{[0.003]}\end{array}$ & $\begin{array}{l}-0.007^{\star * *} \\
{[0.001]}\end{array}$ & $\begin{array}{l}-0.025 \\
{[0.023]}\end{array}$ & $\begin{array}{c}0.02 \\
{[0.013]}\end{array}$ & $\begin{array}{l}0.028^{\star * *} \\
{[0.011]}\end{array}$ \\
\hline $\begin{array}{l}\text { Wants to work more hours in primary } \\
\text { job }\end{array}$ & $\begin{array}{l}0.003 \\
{[0.002]}\end{array}$ & $\begin{array}{l}0.019^{* *} \\
{[0.008]}\end{array}$ & $\begin{array}{l}0.025^{\star *} \\
{[0.010]}\end{array}$ & $\begin{array}{l}-0.003 \\
{[0.004]}\end{array}$ & $\begin{array}{l}-0.131^{*} \\
{[0.077]}\end{array}$ & $\begin{array}{l}-0.067^{\star *} \\
{[0.030]}\end{array}$ & $\begin{array}{l}0.042 \\
{[0.029]}\end{array}$ \\
\hline $\begin{array}{l}\text { Wants to work same hours in primary } \\
\text { job }\end{array}$ & $\{R e f\}$. & $\{$ Ref. $\}$ & $\{R e f\}$. & $\{R e f\}$. & $\{R e f\}$. & $\{$ Ref. $\}$ & $\{R e f\}$. \\
\hline $\begin{array}{l}\text { Wants to work less hours in primary } \\
\text { job }\end{array}$ & $\begin{array}{l}-0.001 \\
{[0.001]}\end{array}$ & $\begin{array}{l}-0.004 \\
{[0.004]}\end{array}$ & $\begin{array}{l}-0.008 \\
{[0.005]}\end{array}$ & $\begin{array}{l}0.001 \\
{[0.002]}\end{array}$ & $\begin{array}{l}-0.01 \\
{[0.044]}\end{array}$ & $\begin{array}{l}0.007 \\
{[0.019]}\end{array}$ & $\begin{array}{l}-0.004 \\
{[0.017]}\end{array}$ \\
\hline Log(Weekly hours in primary job) & $\begin{array}{l}0.001 \\
{[0.002]}\end{array}$ & $\begin{array}{l}0.056^{\star * *} \\
{[0.010]}\end{array}$ & $\begin{array}{l}-0.021^{*} \\
{[0.013]}\end{array}$ & $\begin{array}{l}-0.015^{\star * *} \\
{[0.005]}\end{array}$ & $\begin{array}{l}-0.018 \\
{[0.070]}\end{array}$ & $\begin{array}{l}-0.026 \\
{[0.042]}\end{array}$ & $\begin{array}{l}-0.067^{\star} \\
{[0.039]}\end{array}$ \\
\hline Log(Paid overtime hours) & $\begin{array}{l}-0.001^{\star * *} \\
{[0.000]}\end{array}$ & $\begin{array}{l}0.001 \\
{[0.001]}\end{array}$ & $\begin{array}{l}0.002 \\
{[0.001]}\end{array}$ & $\begin{array}{l}-0.002^{\star \star *} \\
{[0.001]}\end{array}$ & $\begin{array}{l}-0.004 \\
{[0.011]}\end{array}$ & $\begin{array}{l}0.005 \\
{[0.004]}\end{array}$ & $\begin{array}{l}-0.007^{\star} \\
{[0.004]}\end{array}$ \\
\hline Log(Number of minutes to work) & $\begin{array}{l}0.001 \\
{[0.001]}\end{array}$ & $\begin{array}{l}0.008^{* * *} \\
{[0.002]}\end{array}$ & $\begin{array}{l}0.006^{\star *} \\
{[0.003]}\end{array}$ & $\begin{array}{l}0.004^{* * *} \\
{[0.001]}\end{array}$ & - & - & - \\
\hline Private sector & $\begin{array}{l}0.008^{* * *} \\
{[0.001]}\end{array}$ & $\begin{array}{l}0.044^{\star * *} \\
{[0.005]}\end{array}$ & $\begin{array}{l}0.011^{*} \\
{[0.006]}\end{array}$ & $\begin{array}{l}0.004 \\
{[0.003]}\end{array}$ & - & - & - \\
\hline Permanent job & $\begin{array}{l}-0.028^{\star * *} \\
{[0.008]}\end{array}$ & $\begin{array}{l}-0.197^{\star \star \star} \\
{[0.017]}\end{array}$ & $\begin{array}{l}-0.119^{\star \star \star} \\
{[0.018]}\end{array}$ & $\begin{array}{c}-0.140^{\star \star *} \\
{[0.017]}\end{array}$ & - & - & - \\
\hline Promotion prospects & $\begin{array}{l}-0.006^{\star * *} \\
{[0.001]}\end{array}$ & $\begin{array}{l}-0.019^{* * *} \\
{[0.004]}\end{array}$ & $\begin{array}{l}0.052^{\star \star \star} \\
{[0.005]}\end{array}$ & $\begin{array}{l}-0.011^{\star * *} \\
{[0.002]}\end{array}$ & - & - & - \\
\hline Receives annual increments & $\begin{array}{l}-0.006^{\star * *} \\
{[0.001]}\end{array}$ & $\begin{array}{l}-0.016^{\star \star *} \\
{[0.004]}\end{array}$ & $\begin{array}{l}-0.005 \\
{[0.005]}\end{array}$ & $\begin{array}{l}-0.009^{* * *} \\
{[0.002]}\end{array}$ & - & - & - \\
\hline Mills Ratio & - & - & - & - & $\begin{array}{l}0.043 \\
{[0.041]}\end{array}$ & $\begin{array}{l}0.009 \\
{[0.021]}\end{array}$ & $\begin{array}{l}-0.069^{\star * *} \\
{[0.022]}\end{array}$ \\
\hline$\rho$ & $\begin{array}{c}0.270^{\star * *} \\
{[0.021]}\end{array}$ & $\begin{array}{c}0.101^{* * *} \\
{[0.014]}\end{array}$ & $\begin{array}{c}0.103^{* * *} \\
{[0.012]}\end{array}$ & $\begin{array}{c}0.240^{* * *} \\
{[0.022]}\end{array}$ & - & - & - \\
\hline $\begin{array}{l}\text { Observed Probal } \\
\text { Predicted Probak }\end{array}$ & $\begin{array}{l}0.2490 \\
0.0140\end{array}$ & & $\begin{array}{l}0.1562 \\
0.1430\end{array}$ & $\begin{array}{l}0.0 \\
0.0\end{array}$ & & & \\
\hline Number of Obse & 21,751 & 24,456 & 25,134 & 22,432 & 558 & 58 & 4,011 \\
\hline Number of Individuals & 4,729 & 4,975 & 4,968 & 4,872 & 487 & 1,991 & 2,226 \\
\hline Uncensored Observations & - & - & - & - & 22,421 & 25,553 & 26,197 \\
\hline Log-Likelihood & $-2,262.2$ & $-7,811.6$ & $-9,890.1$ & $-4,104.1$ & -333.8 & $-2,313.4$ & $-2,686.6$ \\
\hline
\end{tabular}




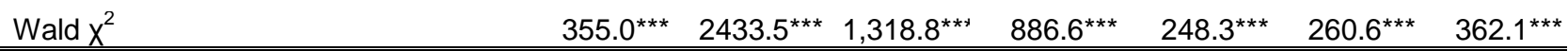

Notes: ${ }^{*} p<0.10,{ }^{* *} p<0.05,{ }^{* * *} p<0.01$. (A1)-(A4) present marginal effects and standard errors from a random effects probit model. (B1)-(B3) show coefficients and bootstrapped standard errors from a linear probability model (based on 1,000 replications). The specifications also include marital status, number of children, partner's employment status and dummy variables for: Occupation $\{9\}$; Education $\{3\}$; Wave $\{15\}$, and a constant term. The significance of the $\rho$ term is given from a LR test that $\rho=0$.

\section{Appendix:}

\section{A.1 Calculation of the difference in earnings (primary occupation vs. next best alternative) $\underline{\text { variable }}$}

The best alternative occupation is detected based on an equation describing the occupational choice in the second job, using a multinomial probit model. Specifically, we let $y_{2 j}$ denote the individual occupational choice of the second job, where $y_{2 j}$ can take the unordered multinomial values $j=\{0,1, \ldots, 9\}$ reflecting the 9 different 1 -digit SOC groups. We then investigate how the set of conditioning variables $v=\left\{y_{1 j}, x\right\}$, where $y_{1 j}$ is the occupation of the individual in the primary job and $\boldsymbol{x}$ captures other demographic and primary job-specific variables, affect the probability of secondary-job selection, $P\left(y_{2 j}=\right.$ $j \mid v)$, ceteris paribus.

Based on the estimates of this model, the predicted probabilities of occupational choice in the second job, conditional on the occupation of the primary job, are shown in Table A1. The best alternative occupations can be easily obtained by looking across each row of Table $A 1$ and selecting the cell with the highest predicted probability, excluding the elements of the diagonal. In doing so, it is evident that, for example, the best alternative occupation in the secondary job for those currently employed as Managers or Administrators in their primary job is an Associated Professional and Technical occupation.

Utilizing the information of Table A1, the predicted wages from the best alternative occupation are hence calculated based on an hourly wage equation model: 
Table A1

Occupational Transitions between $1^{\text {st }}$ and $2^{\text {nd }}$ job: Predicted Probabilities

BHPS, Waves 1-15

\begin{tabular}{|c|c|c|c|c|c|c|c|c|c|c|}
\hline & $\begin{array}{l}\text { Job } \\
\mathbf{1}^{\text {st }} \text { Job }\end{array}$ & $\begin{array}{c}\text { Group } \\
1 \\
\text { Manag. }\end{array}$ & $\begin{array}{c}\text { Group } 2 \\
\text { Profess. }\end{array}$ & $\begin{array}{c}\text { Group } \\
3 \\
\text { Associat } \\
e\end{array}$ & $\begin{array}{l}\text { Group } \\
\quad 4 \\
\text { Clerical }\end{array}$ & $\begin{array}{l}\text { Group } \\
5 \\
\text { Craft }\end{array}$ & $\begin{array}{l}\text { Group } \\
6 \\
\text { Personal }\end{array}$ & $\begin{array}{l}\text { Group } \\
7 \\
\text { Sales }\end{array}$ & $\begin{array}{l}\text { Group } \\
8 \\
\text { Plant }\end{array}$ & $\begin{array}{l}\text { Group } \\
9 \\
\text { Other }\end{array}$ \\
\hline Group & Managers \& administrators & 19.1 & $13.0 \%$ & 23.5 & $6.2 \%$ & $8.1 \%$ & 16.7 & $2.8 \%$ & $4.0 \%$ & $6.7 \%$ \\
\hline Group & Professional occupations & $8.0 \%$ & $36.7 \%$ & 34.3 & $2.7 \%$ & $3.8 \%$ & $5.4 \%$ & $2.6 \%$ & $2.1 \%$ & $4.4 \%$ \\
\hline Group & Assoc. professional \& technical & $7.7 \%$ & $7.0 \%$ & 46.2 & $9.3 \%$ & 10.8 & $7.6 \%$ & $4.6 \%$ & $1.8 \%$ & $5.2 \%$ \\
\hline Group & Clerical \& secretarial occupations & $2.0 \%$ & $3.0 \%$ & 20.6 & 15.9 & 13.9 & 20.3 & $3.5 \%$ & $5.3 \%$ & 15.6 \\
\hline Group & Craft \& related occupations & $3.0 \%$ & $0.7 \%$ & $9.8 \%$ & $0.3 \%$ & 54.3 & 13.7 & $0.8 \%$ & $6.1 \%$ & 11.4 \\
\hline Group & Personal \& protective service occ. & $5.8 \%$ & $3.1 \%$ & $9.9 \%$ & $1.4 \%$ & $8.2 \%$ & 40.2 & $4.9 \%$ & 10.4 & 16.0 \\
\hline Group & Sale & 17.9 & $1.5 \%$ & 26.3 & $4.4 \%$ & 11.4 & 16.1 & 10.0 & $1.7 \%$ & 10.8 \\
\hline Group & Plant \& machine operatives & $2.6 \%$ & $0.2 \%$ & 21.0 & $3.0 \%$ & 13.5 & 26.4 & $2.6 \%$ & 15.8 & 15.0 \\
\hline Group & Other occupations & $8.5 \%$ & $0.7 \%$ & 11.4 & $2.6 \%$ & 21.8 & 22.8 & $3.2 \%$ & $7.5 \%$ & 21.7 \\
\hline
\end{tabular}

Notes:

The Table consists of predicted probabilities of $2^{\text {nd }}$ job occupational choice, conditional on $1^{\text {st }}$ job occupational choice, based on estimates of a Multinomial Probit model (available from the authors upon request).

$$
\ln w_{i t}=x_{i t}^{\prime} \beta+\zeta y_{1(j) i t}+g_{i t}
$$

where, for instance, the predicted wage for Managers or Administrators (SOC code 1) is obtained as $\ln \widehat{w}_{i t(1)}=x_{i t}^{\prime} \hat{\beta}+\hat{\zeta} y_{1(3) i t}$, which is the wage the individuals would receive if they were employed in the next best category of Associated Professional and Technical occupation instead (SOC code 3).

The difference in the earnings capacity between the current and the best alternative occupation is thus calculated as the difference between the wages received from the current occupation in the primary job and the predicted wages from the best alternative occupation in the second job. 